\title{
Synthesis and Preliminary Characterisation of New Silicate, Phosphate and Titanite Reference Glasses
}

\author{
Stephan Klemme (1, 2, 3)*, Stefan Prowatke $(4,5)$, Carsten Münker $(1,6)$, \\ Charles W. Magee (7), Yann Lahaye (8), Thomas Zack (4), Simone A. Kasemann (2), \\ E. Joan A. Cabato (4) and Benjamin Kaeser (2) \\ (1) Institut für Mineralogie, Universitüt Münster, Corrensstrasse 24, 48149 Münster, Germany \\ (2) School of GeoSciences, University of Edinburgh, The Grant Institute, West Mains Rd, Edinburgh EH9 3JW, UK \\ (3) Centre for Science at Extreme Conditions, University of Edinburgh, Erskine Williamson Building, Mayfield Road, Edinburgh EH9 3JZ, UK \\ (4) Mineralogisches Institut, Universität Heidelberg, Im Nevenheimer Feld 236, 69120 Heidelberg, Germany \\ (5) Swarovski AG, 6112 Wattens, Austria \\ (6) Mineralogisch-Petrologisches Institut, Universität Bonn, Poppelsdorfer Schloss, 53115 Bonn, Germany \\ (7) Research School of Earth Sciences, Mills Road, Australian National University, ACT 0200, Australia \\ (8) Institut für Mineralogie, Universität Frankfurt, Senckenberganlage 28, 60054 Frankfurt, Germany \\ * Corresponding author. e-mail: stephan.klemme@ed.ac.uk
}

Eleven synthetic silicate and phosphate glasses were prepared to serve as reference materials for in situ microanalysis of clinopyroxenes, apatite and titanite, and other phosphate and titanite phases.

Analytical results using different micro-analytical techniques showed that the glass fragments were homogeneous in major and trace elements down to the micrometre scale. Trace element determinations using inductively coupled plasma-mass spectrometry (ICP-MS), multi-collector inductively coupled plasma-mass spectrometry (MC-ICP-MS), laser-ablation inductively coupled plasma-mass spectrometry (LA-ICP-MS) and secondary ionisation mass spectrometry (SIMS) showed good agreement for most elements ( $\mathrm{Li}, \mathrm{Be}, \mathrm{B}, \mathrm{Cs}, \mathrm{Rb}, \mathrm{Ba}, \mathrm{Sr}, \mathrm{Ga}, \mathrm{Pb}$, U, Th, Y, La, Ce, Pr, Nd, Sm, Eu, Gd, Er, Tm, Yb, Lu, $\mathrm{Zr}, \mathrm{Hf}, \mathrm{Ta}, \mathrm{Nb}$ ) studied and provide provisional recommended values.

Keywords: glass, reference material, in situ analysis, trace elements, titanite, sphene, apatite, dacite, clinopyroxene, geochemistry.

Received 10 May 07 - Accepted 30 Nov 07
Onze verres synthétiques de compositions silicatée et phosphatée ont été préparés afin de servir de matériaux de référence pour la micro-analyse in situ de clinopyroxènes, d'apatites et de titanites et d'autres phases phosphatées et titanifères. Les résultats analytiques obtenus à partir de différentes techniques de micro-analyse ont montré que les fragments de verre étaient homogènes en éléments majeurs et en trace, ceci jusqu'à l'échelle du micromètre. Les déterminations des concentrations en éléments en trace, faites par spectrométrie de masse à plasma inductif (ICP-MS), spectrométrie de masse à plasma inductif et multi-collecteur (MC-ICP-MS), spectrométrie de masse à plasma inductif et ablation laser (LA-ICP-MS) et spectrométrie de masse à ionisation secondaire (SIMS) ont montré un bon accord entre elles, pour la plupart des éléments étudiés ( $L i, B e, B, C s, R b, B a, S r, G a, P b, U$, Th, Y, La, Ce, Pr, Nd, Sm, Eu, Gd, Er, Tm, Yb, Lu, Zr, $\mathrm{Hf}, \mathrm{Ta}, \mathrm{Nb}$ ) et permettent de proposer des valeurs recommandées provisoires.

Mots-clés : verres, matériaux de référence, analyse in situ, éléments en trace, titanite, sphène, apatite, dacite, clinopyroxène, géochimie.
The geochemical analysis of minerals and geological glasses relies on well characterised reference materials. In an ideal world, homogeneous reference materials should match the chemical compositions of the unknown phase as closely as possible.
However, most geochemical laboratories use National Institute of Standards and Technology certified reference materials (NIST SRM 610 or NIST SRM 612) for the determination of trace elements in minerals and glasses. This could pose a problem as the 
NIST materials are often far removed from the chemical composition of the mineral or glass of interest. Recent advances in in situ determination of trace elements and their isotopes has sparked a particular interest in more appropriate reference materials for the analysis of accessory minerals such as titanites and phosphates. Whilst progress in methods of preparation (Jochum et al. 2000, 2005, 2006) has improved the analysis of natural glasses, homogeneous reference materials for the analysis of minerals are still scarce (Wiedenbeck et al. 1995, Sylvester and Ghaderi 1997, Black et al. 2003, 2004, McDowell et al. 2005, Ødegaard et al. 2005). This is especially true for accessory minerals such as zircon $\left(\mathrm{ZrSiO}_{4}\right)$, apatite $\left(\mathrm{Ca}_{5}\left(\mathrm{PO}_{4}\right)_{3}(\mathrm{OH}, \mathrm{F}, \mathrm{Cl})\right.$, monazite $\left(\mathrm{CePO}_{4}\right)$ and titanite $\left(\mathrm{CaTiSiO}_{5}\right)$, whose compositions are very different from glassy reference materials such as the family of geologically relevant NIST glasses.

To partially address these matters, we have synthesised several novel silicate and phosphate glasses to approximately match the compositions of apatite, clinopyroxene and titanite. The aim of this paper is to describe the synthesis of eleven new reference material glasses together with homogeneity tests and some selected analytical results that may serve as preliminary reference values. We plan to distribute our glasses to interested laboratories over the next few years to collect more analytical data.

\section{Experimental and analytical techniques}

\section{Synthesis}

About 15 grams of each glass were prepared in conventional muffle furnaces in air using large platinum crucibles. Starting materials consisted of oxides, carbonates and phosphates (Table 1) and appropriate amounts were mixed in an agate mortar by hand for at least two hours. Trace elements (see Table 1 for details) were then added to the starting materials using ICP-MS standard solutions or as carbonates or oxides. The phosphate glasses (STDP3 and STDP5) were fused at $1600{ }^{\circ} \mathrm{C}$ for one hour whereas the silicate glasses were fused at $1500{ }^{\circ} \mathrm{C}$ for 3 hours. If necessary, the resulting glasses were re-ground and re-fused. Major element compositions of all eleven glasses are given in Table 2.

Silicate and phosphate melts were quenched by placing the platinum crucible in distilled water. Fragments of the glass were either drilled out of the crucible or carefully broken off. Potential sources of contamination by $\mathrm{Zr}$ or Mo could be due to $\mathrm{ZrO}_{2}$ insulation boards in the muffle furnaces used, as well as from the $\mathrm{MoSi}_{2}$ heating elements of the furnaces. Further sources of contamination were trace impurities in the starting materials. However, the determination of

Table 1.

Starting materials and experimental procedures

\begin{tabular}{|c|c|c|c|c|}
\hline Glass & Starting materials & Trace elements added & $\begin{array}{l}\text { Temperature } \\
\text { of fusion }\left({ }^{\circ} \mathrm{C}\right)\end{array}$ & $\begin{array}{l}\text { Duration } \\
\text { (hr) }\end{array}$ \\
\hline TNT666 & $\mathrm{CaCO}_{3}, \mathrm{TiO}_{2}, \mathrm{Al}_{2} \mathrm{O}_{3}, \mathrm{SiO}_{2}$ & $\mathrm{Li}, \mathrm{Be}, \mathrm{B}, \mathrm{Sc}, \mathrm{Sr}, \mathrm{Zr}, \mathrm{Cs}, \mathrm{La}, \mathrm{Ce}, \mathrm{Gd}, \mathrm{Hf}, \mathrm{Pb}$ & 1500 & 3 \\
\hline TNT777 & $\mathrm{CaCO}_{3}, \mathrm{TiO}_{2}, \mathrm{Al}_{2} \mathrm{O}_{3}, \mathrm{SiO}_{2}$ & $\mathrm{Ga}, \mathrm{Rb}, \mathrm{Y}, \mathrm{Nb}, \mathrm{Ba}, \mathrm{Pr}, \mathrm{Sm}, \mathrm{Lu}, \mathrm{Ta}, \mathrm{Th}, \mathrm{U}$ & 1500 & 3 \\
\hline TNT 150 & $\mathrm{CaCO}_{3}, \mathrm{TiO}_{2}, \mathrm{Al}_{2} \mathrm{O}_{3}, \mathrm{SiO}_{2}$ & $\begin{array}{l}\mathrm{Li}, \mathrm{Be}, \mathrm{B}, \mathrm{Sc}, \mathrm{Rb}, \mathrm{Sr}, \mathrm{Y}, \mathrm{Zr}, \mathrm{Nb}, \mathrm{Cs}, \mathrm{Ba}, \mathrm{La}, \\
\mathrm{Ce}, \mathrm{Pr}, \mathrm{Sm}, \mathrm{Gd}, \mathrm{Lu}, \mathrm{Hf}, \mathrm{Ta}, \mathrm{Pb}, \mathrm{Th}, \mathrm{U}\end{array}$ & 1500 & 3 \\
\hline TNT1500 & $\mathrm{CaO}, \mathrm{TiO}_{2}, \mathrm{Al}_{2} \mathrm{O}_{3}, \mathrm{SiO}_{2}$ & $\begin{array}{l}\mathrm{Li}, \mathrm{Be}, \mathrm{B}, \mathrm{Sc}, \mathrm{Rb}, \mathrm{Sr}, \mathrm{Y}, \mathrm{Zr}, \mathrm{Nb}, \mathrm{Cs}, \mathrm{Ba}, \mathrm{La}, \\
\mathrm{Ce}, \mathrm{Pr}, \mathrm{Sm}, \mathrm{Gd}, \mathrm{Lu}, \mathrm{Hf}, \mathrm{Ta}, \mathrm{Pb}, \mathrm{Th}, \mathrm{U}\end{array}$ & 1500 & 3 \\
\hline CPX666 & $\mathrm{Al}_{2} \mathrm{O}_{3}, \mathrm{SiO}_{2}, \mathrm{~K}_{2} \mathrm{CO}_{3}, \mathrm{CaCO}_{3}$ & $\mathrm{Li}, \mathrm{Be}, \mathrm{B}, \mathrm{Sc}, \mathrm{Sr}, \mathrm{Zr}, \mathrm{Cs}, \mathrm{La}, \mathrm{Ce}, \mathrm{Gd}, \mathrm{Hf}, \mathrm{Pb}$ & 1500 & 3 \\
\hline CPX777 & $\mathrm{Al}_{2} \mathrm{O}_{3}, \mathrm{SiO}_{2}, \mathrm{~K}_{2} \mathrm{CO}_{3}, \mathrm{CaCO}_{3}$ & $\mathrm{Ga}, \mathrm{Rb}, \mathrm{Y}, \mathrm{Nb}, \mathrm{Ba}, \mathrm{Pr}, \mathrm{Sm}, \mathrm{Lu}, \mathrm{Ta}, \mathrm{Th}, \mathrm{U}$ & 1500 & 3 \\
\hline DAC666 & $\mathrm{Na}_{2} \mathrm{CO}_{3}, \mathrm{Al}_{2} \mathrm{O}_{3}, \mathrm{SiO}_{2}, \mathrm{~K}_{2} \mathrm{CO}_{3}, \mathrm{CaCO}_{3}, \mathrm{TiO}_{2}$ & $\mathrm{Li}, \mathrm{Be}, \mathrm{B}, \mathrm{Sc}, \mathrm{Sr}, \mathrm{Zr}, \mathrm{Cs}, \mathrm{La}, \mathrm{Ce}, \mathrm{Gd}, \mathrm{Hf}, \mathrm{Pb}$ & 1500 & 1 \\
\hline DAC777 & $\mathrm{Na}_{2} \mathrm{CO}_{3}, \mathrm{Al}_{2} \mathrm{O}_{3}, \mathrm{SiO}_{2}, \mathrm{~K}_{2} \mathrm{CO}_{3}, \mathrm{CaCO}_{3}, \mathrm{TiO}_{2}$ & $\mathrm{Ga}, \mathrm{Rb}, \mathrm{Y}, \mathrm{Nb}, \mathrm{Ba}, \mathrm{Pr}, \mathrm{Sm}, \mathrm{Lu}, \mathrm{Ta}, \mathrm{Th}, \mathrm{U}$ & 1500 & 1 \\
\hline STDP5 & $\mathrm{CaCO}_{3}, \mathrm{NH}_{4} \mathrm{H}_{2} \mathrm{PO}_{4}$ & $\begin{array}{l}\mathrm{Li}, \mathrm{Be}, \mathrm{B}, \mathrm{Sc}, \mathrm{Rb}, \mathrm{Sr}, \mathrm{Y}, \mathrm{Zr}, \mathrm{Nb}, \mathrm{Cs}, \mathrm{Ba}, \mathrm{La}, \\
\mathrm{Ce}, \mathrm{Pr}, \mathrm{Sm}, \mathrm{Gd}, \mathrm{Lu}, \mathrm{Hf}, \mathrm{Ta}, \mathrm{Pb}, \mathrm{Th}, \mathrm{U}\end{array}$ & 1600 & 1 \\
\hline STDP3-150 & $\mathrm{CaCO}_{3}, \mathrm{Al}_{2} \mathrm{O}_{3}, \mathrm{MgO}, \mathrm{SiO}_{2}, \mathrm{NH}_{4} \mathrm{H}_{2} \mathrm{PO}_{4}$ & $\begin{array}{l}\mathrm{Li}, \mathrm{Be}, \mathrm{B}, \mathrm{Sc}, \mathrm{Rb}, \mathrm{Sr}, \mathrm{Y}, \mathrm{Zr}, \mathrm{Nb}, \mathrm{Cs}, \mathrm{Ba}, \mathrm{La}, \\
\mathrm{Ce}, \mathrm{Pr}, \mathrm{Sm}, \mathrm{Gd}, \mathrm{Lu}, \mathrm{Hf}, \mathrm{Ta}, \mathrm{Pb}, \mathrm{Th}, \mathrm{U}\end{array}$ & 1600 & 1 \\
\hline STDP3-1500 & $\mathrm{CaCO}_{3}, \mathrm{Al}_{2} \mathrm{O}_{3}, \mathrm{MgO}, \mathrm{SiO}_{2}, \mathrm{NH}_{4} \mathrm{H}_{2} \mathrm{PO}_{4}$ & $\begin{array}{l}\mathrm{Li}, \mathrm{Be}, \mathrm{B}, \mathrm{Sc}, \mathrm{Rb}, \mathrm{Sr}, \mathrm{Y}, \mathrm{Zr}, \mathrm{Nb}, \mathrm{Cs}, \mathrm{Ba}, \mathrm{La}, \\
\mathrm{Ce}, \mathrm{Pr}, \mathrm{Sm}, \mathrm{Gd}, \mathrm{Lu}, \mathrm{Hf}, \mathrm{Ta}, \mathrm{Pb}, \mathrm{Th}, \mathrm{U}\end{array}$ & 1600 & 1 \\
\hline
\end{tabular}

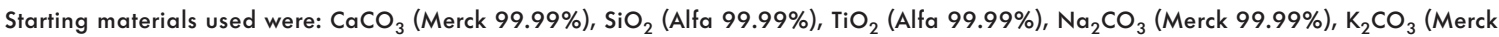
99.99\%), $\mathrm{MgO}$ (Alfa 99.99\%), $\mathrm{NH}_{4} \mathrm{H}_{2} \mathrm{PO}_{4}$ (Alfa 99.9\%), $\mathrm{Al}_{2} \mathrm{O}_{3}$ (Merck 99.99\%). Note that $\mathrm{MgO}, \mathrm{TiO}_{2}, \mathrm{SiO}_{2}$ and $\mathrm{Al}_{2} \mathrm{O}_{3}$ were fired at $1000{ }^{\circ} \mathrm{C}$ for five hours to release any adsorbed water, hydroxides and other volatile impurities. The fired oxides were then kept in a laboratory dry furnace at $110^{\circ} \mathrm{C}$. 
Table 2.

Major element composition of glasses

\begin{tabular}{l|l|l|l|l|l|l|l|l|l}
\hline & \multicolumn{1}{|c|}{$\mathbf{N a}_{\mathbf{2}} \mathbf{O}$} & \multicolumn{1}{|c|}{$\mathbf{K}_{\mathbf{2}} \mathbf{O}$} & $\mathbf{C a O}$ & $\mathbf{M g O}$ & $\mathbf{T i O}_{\mathbf{2}}$ & $\mathbf{A l}_{\mathbf{2}} \mathbf{O}_{\mathbf{3}}$ & $\mathbf{S i O}_{\mathbf{2}}$ & $\mathbf{P}_{\mathbf{2}} \mathbf{O}_{\mathbf{5}}$ & $\mathbf{T o t a l}$ \\
\hline TNT666 & $0.016(15)$ & $0.08(3)$ & $28.04(25)$ & b.d. & $39.65(41)$ & b.d. & $30.14(28)$ & n.a. & 97.9 \\
TNT777 & b.d. & $0.06(2)$ & $27.91(24)$ & b.d. & $39.55(39)$ & b.d. & $29.96(22)$ & n.a. & 97.5 \\
TNT150 & $0.013(10)$ & $0.084(14)$ & $28.16(14)$ & b.d. & $39.86(20)$ & $0.11(1)$ & $29.97(13)$ & n.a. & 98.2 \\
TNT1500 & $0.024(16)$ & $0.10(14)$ & $27.30(14)$ & b.d. & $38.86(18)$ & $0.12(1)$ & $28.86(13)$ & n.a. & 95.3 \\
CPX666 & $0.04(2)$ & $0.024(19)$ & $25.21(260$ & $14.09(15)$ & $6.91(16)$ & $8.72(13)$ & $42.9(3)$ & n.a. & 97.9 \\
CPX777 & $0.029(24)$ & $0.018(17)$ & $25.02(27)$ & $14.06(15)$ & $6.92(17)$ & $8.72(12)$ & $42.9(2)$ & n.a. & 97.7 \\
DAC666 & $4.37(13)$ & $3.19(11)$ & $8.08(17)$ & b.d. & $2.76(7)$ & $15.33(19)$ & $64.32(28)$ & n.a. & 98.1 \\
DAC777 & $4.2(1)$ & $3.2(1)$ & $7.97(15)$ & b.d. & $2.73(12)$ & $15.32(17)$ & $64.04(29)$ & n.a. & 97.6 \\
STDP5 & - & - & $31.81(12)$ & - & - & - & - & $65.91(13)$ & 97.7 \\
STDP3-150 & - & - & $21.1(1)$ & $10.7(2)$ & - & $13.5(1)$ & $46.51(15)$ & $7.8(5)$ & 99.7 \\
STDP3-1500 & - & - & $20.4(2)$ & $10.4(1)$ & - & $13.1(2)$ & $45.1(2)$ & $7.6(3)$ & 96.6 \\
\hline
\end{tabular}

Results from electron probe microanalysis from several fragments of each glass $(\% \mathrm{~m} / \mathrm{m})$. Uncertainties (2RSD) from multiple analyses ( 100 ) are given in brackets as last significant digits; e.g., 3.19 (11) should be read as $3.19 \pm 0.11$ or 3.1 (12) should be read as $3.1 \pm 1.2$. b.d = below limit of detection, n.a. = not analysed. TNT glasses represent glasses of titanite composition, the CPX glasses approximate Ti-rich clinopyroxene compositions, the DAC compositions are to represent dacitic compositions, and the STDP glasses are phosphate-glasses of varying compositions.

elements such as Tm, which was not added to the starting material, yielded values of only a few $\mu \mathrm{g} \mathrm{g}^{-1}$.

Synthesis of Ti-rich silicate glasses (TNT) was straightforward. However, the preparation of phosphate-bearing glasses (STDP) was much more complicated than was anticipated. The preparation of silicate glass with significant amounts of phosphorus was straightforward, but exsolution of immiscible phosphate liquids was encountered in some cases. In these cases, compositions were altered to prevent exsolution of immiscible phases. However, the synthesis of glasses which only contained calcium and phosphorus, and which would be ideal as reference materials for the analysis of whitlockite or apatite, turned out to be much more complicated. Glasses with high $\mathrm{Ca} / \mathrm{P}(\mathrm{Ca} / \mathrm{P}$ > 65 molar) could not be synthesised in our laboratories as melting points commonly exceeded $1600{ }^{\circ} \mathrm{C}$. In systems with $\mathrm{Ca} / \mathrm{P}=50$ only very small amounts of glass could be synthesised as quench crystallisation of phosphate minerals often occurred. These materials are not presented here. However, we succeeded in preparing large quantities of phosphate glasses with $\mathrm{Ca} / \mathrm{P}<45$ (Sinha et al. 2001).

\section{Analytical methods}

\section{Electron probe microanalysis (EPMA)}

A Cameca SX51 wavelength dispersive 5 spectrometer electron microprobe was used at Heidelberg University to determine major element compositions and test homogeneity of several chips of each silicate and phosphate glass. We used an acceleration voltage of $15 \mathrm{kV}$ which resulted in a probe current of $20 \mathrm{nA}$ and each element was counted for 10 seconds (Prowatke and Klemme 2006). To minimise possible loss of alkali metals such as $\mathrm{Na}$ or $\mathrm{K}$, these elements were measured first and the beam diameter was enlarged to $10 \mu \mathrm{m}$. Profile lengths of up to $2000 \mu \mathrm{m}$ (up to 100 points) were measured across small fragments of the glasses. The overall analytical uncertainty of the method was typically smaller than $2 \%(2 s)$ for all major elements studied.

\section{Secondary ion mass spectrometry (SIMS)}

A Cameca ims $3 f$ ion probe at Heidelberg University was used to investigate trace element homogeneity in the glasses, using a nominal $10 \mathrm{kV}$ primary beam of $160^{-}$ions. Positive secondary ions were accelerated to $4.5 \mathrm{keV}$. The energy window was set at 40 $\mathrm{eV}$. We employed the energy filtering technique with an offset of $90 \mathrm{eV}$ at a mass resolution $M / \Delta M(10 \%)$ of $\approx 400$ to suppress interfering molecules and to minimise matrix effects. The primary current was $20 \mathrm{nA}$, resulting in a spatial resolution of ca. 20-25 $\mu \mathrm{m}$ diameter at the sample surface. Details of the analytical procedures are given by Prowatke and Klemme (2005). Profiles of SIMS analyses were done across all glass fragments and profile lengths varied between 200 and $2000 \mu \mathrm{m}$ with distances between individual spots ranging between 50 and $100 \mu \mathrm{m}$. 


\section{Inductively coupled plasma-mass spectrometry (ICP-MS)}

The analyses using inductively coupled plasmamass spectrometry were performed at the ACME laboratories in Vancouver, Canada. An Elan inductively coupled plasma-mass spectrometer (Perkin Elmer) was used. The powdered sample $(0.25 \mathrm{~g})$ was decomposed by a mixed acid digestion $\left(\mathrm{HClO}_{4}\right.$ $\mathrm{HNO}_{3}-\mathrm{HCl}$ ) procedure under pressure. Rhenium served as the internal standard to correct for drift. The precision was generally better than 5\% (2s) and total analytical uncertainties were estimated to be better than $10 \%$.

\section{Multi collector-inductively coupled plasma-mass spectrometry (MC-ICP-MS)}

Measurements were performed at the Zentrallabor für Geochronologie (ZLG) at the University of Münster, Germany. During the course of the measurements, two 1.3 and $3.6 \mathrm{mg}$ fragments of TNT 150 and one $0.86 \mathrm{mg}$ fragment of TNT 1500 were analysed by MC-ICP-MS. Contents of some HFSE ( $\mathrm{Zr}, \mathrm{HF}, \mathrm{Nb}$, Ta) and Lu together with the $176 \mathrm{Hf} / 177 \mathrm{Hf}$ isotope compositions were measured using an Isoprobe MC-ICP-MS. Operating conditions and analytical techniques are summarised in Münker et al. (2001) and Weyer et al. (2002). Hafnium isotope results are given relative to a value of 0.282160 for JMC 475 , the typical external reproducibility was \pm 0.5 $\varepsilon$-units $(2 s)$. Concentrations of the HFSE (except for $\mathrm{Nb}$ ) were measured by isotope dilution using a mixed $94 \mathrm{Zr}$ $180 \mathrm{Hf}-180 \mathrm{Ta}-176 \mathrm{Lu}$ isotope tracer which was calibrated against > $99.9 \%$ pure AMES metals. Niobium concentrations were measured as $\mathrm{Zr} / \mathrm{Nb}$ against a $\mathrm{Zr}-\mathrm{Nb}$ reference sample prepared by AMES metals and using the $\mathrm{Zr}$ concentrations determined from the isotope dilution measurements. Typical accuracies and $2 s$ external reproducibilities were $\pm 1 \%$ for $\mathrm{Zr}, \mathrm{Hf}$ and $\mathrm{Ta}$ and $\pm 4 \%$ for $\mathrm{Nb}$ concentrations. Typical external reproducibilities for $\mathrm{Nb} / \mathrm{Ta}, \mathrm{ZrHf}$ and $\mathrm{Lu} / \mathrm{Hf}$ are $\pm 4 \%, \pm 0.6 \%$, and $\pm 1 \%$, respectively. Errors as quoted in Table 6 also include propagated errors originating from blank measurements, assuming a $\pm 50 \%$ blank uncertainty. Results between the two replicates of TNT 150 agree within the external reproducibilities quoted above (Table 6). Measured blanks were $550 \mathrm{ng}$ for $\mathrm{Zr}, 39 \mathrm{pg}$ for $\mathrm{Hf}, 9 \mathrm{pg}$ for $\mathrm{Nb}$, and $17 \mathrm{pg}$ for Ta.

\section{Laser ablation-inductively coupled plasma-mass spectrometry (LA-ICP-MS)}

Laser ICP-MS analysis at the Australian National University were performed using an Agilent 7500 series mass spectrometer. The Resonetics $193 \mathrm{~nm}$ excimer laser was attenuated using a 25\% reflectance mirror on the final bend of the custom-built laser flight tube. Laser optics, ablation cell geometry, and signal smoothing devices are described in Eggins et al. (2003). Ablation took place at $5 \mathrm{~Hz}$, using a $60 \mu \mathrm{m}$ spot. Analysis time was 60 seconds, with 45 seconds of background collection before ablation commenced. The following masses were measured: ${ }^{7 \mathrm{Li}},{ }^{9} \mathrm{Be},{ }^{11} \mathrm{~B}$, $23 \mathrm{Na}, 24 \mathrm{Mg}, 29 \mathrm{Si}, 31 \mathrm{P}, 33 \mathrm{~S}, 43 \mathrm{Ca}, 55 \mathrm{Mn}, 67 \mathrm{Zn}, 68 \mathrm{Zn}$, ${ }^{71} \mathrm{Ga}, 84 \mathrm{Sr}, 85 \mathrm{Rb}, 88 \mathrm{Sr}, 89 \mathrm{Y}, 90 \mathrm{Zr}, 91 \mathrm{Zr}, 93 \mathrm{Nb},{ }^{111} \mathrm{Cd},{ }^{133} \mathrm{Cs}$, $137 \mathrm{Ba}, 139 \mathrm{La}, 140 \mathrm{Ce}, 141 \mathrm{Pr}, 146 \mathrm{Nd}, 147 \mathrm{Sm}, 153 \mathrm{Eu}, 157 \mathrm{Gd}$, $166 \mathrm{Er}, 172 \mathrm{~Tb}, 175 \mathrm{Lu}, 178 \mathrm{Hf}, 181 \mathrm{Ta}, 208 \mathrm{~Pb}, 232 \mathrm{Th}, 238 \mathrm{U}$. All isotopes were counted for $10 \mathrm{~ms}$. Including switching time, this cycle was repeated every 0.4502 seconds.

The laser ablation ICP-MS system at the Universität Frankfurt, Germany consisted of a New Wave $213 \mathrm{~nm}$ Nd:YAG laser (LUV-213) and a ThermoFinnigan Element 2 mass spectrometer. The laser was run at a pulse frequency of $10 \mathrm{~Hz}$ and a pulse energy of 0.8 $\mathrm{mJ}$ for a $75 \mu \mathrm{m}$ spot size. For each sample, five consecutives measurements were performed. An Ar-He sample gas mixture served as carrier gas. ${ }^{44} \mathrm{Ca}$ was used as an internal standard and NIST SRM 612 (Pearce et al. 1997) was used for calibration.

\section{Results and discussion}

\section{Homogeneity of the glasses}

Homogeneity in terms of major and trace elements of any reference material is of fundamental importance. We, therefore, tested both major and trace element homogeneity of several fragments of each glass using electron microprobe, SIMS and laser ablation ICP-MS techniques. As a measure of variation across samples, we selected the two times relative standard deviation (2 RSD) of multiple analyses across several glass fragments in percent or, in case of the SIMS homogeneity tests, the relative variation of count rates of elements relative to internal standard elements such as $\mathrm{Si}$ or $\mathrm{Ca}$.

\section{Major element homogeneity}

We investigated homogeneity using several glass fragments of each of the eleven glasses. Electron 
Table 3.

Reproducibility (\%) of major element determination using electron probe microanalysis

\begin{tabular}{|c|c|c|c|c|c|c|c|c|c|c|c|}
\hline & $\begin{array}{l}\text { TNT } \\
666\end{array}$ & $\begin{array}{l}\text { TNT } \\
777\end{array}$ & $\begin{array}{l}\text { TNT } \\
150\end{array}$ & $\begin{array}{c}\text { TNT } \\
1500\end{array}$ & $\begin{array}{l}\text { CPX } \\
666\end{array}$ & $\begin{array}{l}\text { CPX } \\
777\end{array}$ & $\begin{array}{l}\text { DAC } \\
666\end{array}$ & $\begin{array}{l}\text { DAC } \\
777\end{array}$ & $\begin{array}{c}\text { STDP } \\
5\end{array}$ & STDP3-150 & STDP3-1500 \\
\hline $\mathrm{Na}_{2} \mathrm{O}$ & 93.8 & - & 76.9 & 66.7 & 50 & 82.8 & 3.0 & 2.4 & - & - & - \\
\hline $\mathrm{K}_{2} \mathrm{O}$ & 37.5 & 33.33 & 16.67 & 140.0 & 79.2 & 94.4 & 3.4 & 3.1 & - & - & - \\
\hline $\mathrm{CaO}$ & 0.9 & 0.9 & 0.5 & 0.5 & 1 & 1.1 & 2.1 & 1.9 & 0.4 & 0.5 & 0.8 \\
\hline $\mathrm{MgO}$ & - & - & - & - & 1.1 & 1.1 & - & - & - & 1.9 & 0.1 \\
\hline $\mathrm{TiO}_{2}$ & - & - & - & - & 2.3 & 2.5 & 2.5 & 4.4 & - & - & - \\
\hline $\mathrm{Al}_{2} \mathrm{O}_{3}$ & - & - & 9.1 & 8.3 & 1.5 & 1.4 & 1.2 & 1.1 & - & 0.7 & 1.1 \\
\hline $\mathrm{SiO}_{2}$ & 0.9 & 0.7 & 0.4 & 0.5 & 0.7 & 0.5 & 0.4 & 0.5 & - & 0.3 & 0.4 \\
\hline $\mathrm{P}_{2} \mathrm{O}_{5}$ & - & - & - & - & - & - & - & - & 0.2 & 1.8 & 1.5 \\
\hline
\end{tabular}

Given are relative standard deviations in percent (1 RSD) of multiple analyses ( 250$)$ using the electron microprobe (mainly as line scans across glass fragments) of several fragments of the individual glasses. Note that some of the high errors (e.g., Na and K in the TNT and CPX glasses) are mainly due to low concentrations of the element of interest close to the limit of detection with consequently poor counting statistics.

Table 4.

Homogeneity tests of all glasses using laser ablation ICP-MS: standard deviations of multiple analyses

\begin{tabular}{|c|c|c|c|c|c|c|c|c|c|c|c|}
\hline & STDP3-1500 & STDP3-150 & $\begin{array}{c}\text { STDP } \\
5\end{array}$ & $\begin{array}{l}\text { TNT } \\
150\end{array}$ & $\begin{array}{c}\text { TNT } \\
1500\end{array}$ & $\begin{array}{l}\text { TNT } \\
666\end{array}$ & $\begin{array}{l}\text { TNT } \\
777\end{array}$ & $\begin{array}{l}\text { Cpx } \\
666\end{array}$ & $\begin{array}{l}\text { Cpx } \\
777\end{array}$ & $\begin{array}{l}\text { DAC } \\
777\end{array}$ & $\begin{array}{l}\text { DAC } \\
666\end{array}$ \\
\hline $\mathrm{Li}$ & 0.84 & 1.67 & 1.07 & 1.20 & 0.26 & 1.02 & 7.82 & 1.49 & 0.69 & 0.77 & 0.65 \\
\hline $\mathrm{Be}$ & 0.45 & 0.64 & 0.45 & 1.28 & 0.55 & 0.39 & 10.04 & 0.87 & 5.86 & 5.94 & 0.61 \\
\hline B & 0.91 & 0.28 & 0.43 & 1.65 & 0.66 & 1.40 & 2.51 & 1.30 & 1.88 & 8.93 & 1.04 \\
\hline Cs & 0.79 & 1.07 & 0.74 & 0.30 & 0.99 & 0.67 & 0.65 & 0.57 & 0.85 & 0.89 & 1.71 \\
\hline $\mathrm{Rb}$ & 0.75 & 0.93 & 0.63 & 0.25 & 0.60 & 0.37 & 0.46 & 1.13 & 0.79 & 0.62 & 1.20 \\
\hline $\mathrm{Ba}$ & 0.30 & 0.45 & 0.72 & 0.68 & 0.32 & 1.54 & 0.13 & 1.94 & 0.63 & 0.32 & 3.69 \\
\hline $\mathrm{Sr}$ & 0.42 & 0.28 & 0.29 & 0.24 & 0.57 & 0.16 & 1.04 & 0.24 & 0.81 & 1.14 & 0.86 \\
\hline $\mathrm{Ga}$ & 0.45 & 0.53 & 0.67 & 0.30 & 0.97 & 0.34 & 0.13 & 0.57 & 0.66 & 0.26 & 0.80 \\
\hline $\mathrm{Pb}$ & 0.81 & 0.37 & 1.16 & 0.40 & 0.99 & 1.46 & 1.12 & 1.50 & 1.32 & 21.04 & 3.23 \\
\hline$U$ & 0.45 & 0.72 & 1.48 & 0.12 & 0.66 & 0.95 & 0.06 & 0.92 & 0.55 & 5.75 & 3.63 \\
\hline Th & 0.55 & 0.61 & 1.28 & 0.15 & 1.04 & 3.62 & 0.37 & 3.32 & 0.29 & 0.27 & 4.28 \\
\hline Y & 0.52 & 0.62 & 0.22 & 0.04 & 0.67 & 0.48 & 0.14 & 0.62 & 0.26 & 0.29 & 1.79 \\
\hline La & 0.59 & 0.37 & 0.87 & 0.14 & 0.71 & 0.38 & 0.84 & 0.30 & 0.79 & 1.02 & 1.32 \\
\hline $\mathrm{Ce}$ & 0.41 & 0.60 & 0.79 & 0.42 & 0.62 & 0.29 & 2.73 & 0.30 & 0.83 & 0.80 & 1.84 \\
\hline $\operatorname{Pr}$ & 0.41 & 0.45 & 0.88 & 0.15 & 0.61 & 3.17 & 0.31 & 7.40 & 2.13 & 0.23 & 1.77 \\
\hline $\mathrm{Nd}$ & 8.79 & 8.90 & 4.24 & 3.74 & 2.27 & 19.55 & 6.15 & 15.15 & 10.66 & 2.33 & 10.31 \\
\hline $\mathrm{Sm}$ & 0.27 & 0.51 & 0.90 & 0.09 & 0.58 & 1.90 & 0.30 & 2.10 & 0.37 & 0.20 & 3.33 \\
\hline Eu & 7.64 & 14.55 & 2.16 & 8.40 & 2.98 & 7.68 & 3.86 & 13.59 & 4.13 & 8.84 & 28.70 \\
\hline $\mathrm{Gd}$ & 0.37 & 0.40 & 1.12 & 0.56 & 0.39 & 0.59 & 2.29 & 0.60 & 1.82 & 0.71 & 1.78 \\
\hline Er & 6.51 & 12.73 & 4.89 & 1.98 & 2.82 & 9.70 & 10.54 & 21.83 & 2.53 & 7.80 & 6.73 \\
\hline Yb & 5.45 & 3.99 & 3.85 & 5.32 & 1.78 & 7.39 & 1.30 & 11.04 & 1.79 & 4.84 & 5.59 \\
\hline Lu & 0.70 & 0.44 & 1.23 & 0.23 & 0.87 & 1.89 & 0.10 & 2.44 & 0.04 & 0.16 & 2.59 \\
\hline $\mathrm{Zr}$ & 0.48 & 1.30 & 0.42 & 0.17 & 0.53 & 0.33 & 0.15 & 0.26 & 0.52 & 0.78 & 0.80 \\
\hline $\mathrm{Hf}$ & 0.50 & 0.53 & 1.40 & 0.14 & 0.59 & 0.58 & 2.32 & 0.68 & 2.72 & 2.59 & 2.22 \\
\hline $\mathrm{Ta}$ & 0.68 & 0.39 & 1.19 & 0.13 & 0.69 & 1.01 & 0.20 & 1.79 & 0.20 & 0.31 & 2.14 \\
\hline $\mathrm{Nb}$ & 0.62 & 0.57 & 0.58 & 0.09 & 0.36 & 0.09 & 0.25 & 0.66 & 0.34 & 0.24 & 1.83 \\
\hline
\end{tabular}

Given are relative standard deviations (2 RSD, percent) of multiple analyses (mainly as multiple spots in lines across glass fragments) of several fragments of the individual glasses. Note that some of the high errors (e.g., Eu or Er in all glasses) are mainly due low concentrations of the element of interest close to the limit of detection, hence with consequently poor counting statistics. In this context it should be noted that the glasses have not been doped with either Eu, Nd or Er.

probe microanalysis profiles were performed across these fragments with spots spaced between 10 and $20 \mu \mathrm{m}$ apart. Profiles ranged from about $200 \mu \mathrm{m}$ to more than $2000 \mu \mathrm{m}$. Results of these profiles are given in Table 2 and reproducibility of the analytical results are indicated in Table 3.

\section{Trace element homogeneity}

In situ analytical techniques such as laser ablation ICP-MS or SIMS are the methods of choice to investigate the trace element homogeneity of the glasses. Several fragments of all glasses (including the DAC and 
Table 5.

Results from homogeneity tests of some selected glasses using SIMS

\begin{tabular}{|c|c|c|c|c|c|c|c|c|}
\hline Isotope (X) & $\begin{array}{l}\text { TNT } 150 \\
\mathrm{X}^{+/ 30} \mathbf{S i}^{+}\end{array}$ & 1 RSD & $\begin{array}{l}\text { TNT } 1500 \\
\mathrm{X}^{+} / 30 \mathrm{Si}^{+}\end{array}$ & 1 RSD & $\begin{array}{c}\text { STDP5 } \\
\mathrm{X}^{+} / 44 \mathrm{Ca}^{+}\end{array}$ & 1 RSD & $\begin{array}{c}\text { STDP3-150 } \\
\mathrm{X}^{+} / 30 \mathrm{Si}^{+}\end{array}$ & 1 RSD \\
\hline${ }^{85} \mathrm{Rb}$ & 6.38E-03 & $0.77 \%$ & 5.93E-02 & $0.44 \%$ & $2.16 \mathrm{E}-02$ & $0.49 \%$ & $2.85 \mathrm{E}-03$ & $1.35 \%$ \\
\hline $88 \mathrm{Sr}$ & 3.07E-02 & $0.73 \%$ & $2.55 \mathrm{E}-01$ & $0.41 \%$ & 9.33E-02 & $0.25 \%$ & $1.50 \mathrm{E}-02$ & $0.70 \%$ \\
\hline 89Y & $3.72 \mathrm{E}-02$ & $0.25 \%$ & $3.85 \mathrm{E}-01$ & $0.27 \%$ & $1.29 \mathrm{E}-01$ & $0.33 \%$ & $1.78 \mathrm{E}-02$ & $0.83 \%$ \\
\hline $90 \mathrm{Zr}$ & 2.09E-02 & $0.68 \%$ & $1.49 \mathrm{E}-01$ & $0.25 \%$ & 4.25E-02 & $0.43 \%$ & $7.26 \mathrm{E}-03$ & $1.49 \%$ \\
\hline $93 \mathrm{Nb}$ & $1.79 \mathrm{E}-02$ & $0.53 \%$ & $1.49 \mathrm{E}-01$ & $0.42 \%$ & $4.78 \mathrm{E}-02$ & $0.38 \%$ & $7.22 \mathrm{E}-03$ & $1.21 \%$ \\
\hline${ }^{133} \mathrm{Cs}$ & 4.03E-03 & $0.95 \%$ & 3.07E-02 & $0.86 \%$ & $1.70 \mathrm{E}-02$ & $0.65 \%$ & $2.13 \mathrm{E}-03$ & $1.07 \%$ \\
\hline${ }^{138} \mathrm{Ba}$ & $1.00 \mathrm{E}-02$ & $0.56 \%$ & $9.48 \mathrm{E}-02$ & $0.49 \%$ & $3.61 \mathrm{E}-02$ & $0.48 \%$ & 4.14E-03 & $1.18 \%$ \\
\hline${ }^{139} \mathrm{La}$ & $1.43 \mathrm{E}-02$ & $0.91 \%$ & $1.51 \mathrm{E}-01$ & $0.65 \%$ & 5.64E-02 & $0.36 \%$ & 6.96E-03 & $0.93 \%$ \\
\hline${ }^{140} \mathrm{Ce}$ & $1.43 \mathrm{E}-02$ & $0.80 \%$ & $1.44 \mathrm{E}-01$ & $0.30 \%$ & $5.46 \mathrm{E}-02$ & $0.32 \%$ & 6.86E-03 & $0.76 \%$ \\
\hline${ }^{141} \mathrm{Pr}$ & $1.69 \mathrm{E}-02$ & $0.47 \%$ & $1.80 \mathrm{E}-01$ & $0.47 \%$ & 6.42E-02 & $0.56 \%$ & 7.86E-03 & $0.15 \%$ \\
\hline${ }^{147} \mathrm{Sm}$ & 2.77E-03 & $1.19 \%$ & $2.76 \mathrm{E}-02$ & $0.80 \%$ & $1.06 \mathrm{E}-02$ & $0.56 \%$ & $1.34 \mathrm{E}-03$ & $1.31 \%$ \\
\hline $160 \mathrm{Gd}$ & 3.30E-03 & $1.42 \%$ & 3.33E-02 & $0.69 \%$ & $1.40 \mathrm{E}-02$ & $0.61 \%$ & $1.84 \mathrm{E}-03$ & $0.50 \%$ \\
\hline 175Lu & 1.10E-02 & $1.03 \%$ & $1.17 \mathrm{E}-01$ & $0.62 \%$ & $3.96 \mathrm{E}-02$ & $0.52 \%$ & $5.95 \mathrm{E}-03$ & $0.28 \%$ \\
\hline $178 \mathrm{Hf}$ & $1.64 \mathrm{E}-03$ & $1.58 \%$ & 1.77E-02 & $0.75 \%$ & 5.83E-03 & $1.52 \%$ & $1.03 \mathrm{E}-03$ & $1.46 \%$ \\
\hline${ }^{181} \mathrm{Ta}$ & $2.73 \mathrm{E}-03$ & $0.90 \%$ & 2.77E-02 & $1.08 \%$ & $1.02 \mathrm{E}-02$ & $0.88 \%$ & $1.73 E-03$ & $1.40 \%$ \\
\hline $208 \mathrm{~Pb}$ & 3.64E-04 & $1.87 \%$ & $3.56 \mathrm{E}-03$ & $1.16 \%$ & $3.51 \mathrm{E}-04$ & $3.05 \%$ & $6.24 \mathrm{E}-05$ & $2.88 \%$ \\
\hline 232Th & 3.59E-03 & $1.76 \%$ & 3.89E-02 & $1.14 \%$ & $1.91 \mathrm{E}-02$ & $0.88 \%$ & $2.91 \mathrm{E}-03$ & $0.66 \%$ \\
\hline $238 \mathrm{U}$ & 3.88E-03 & $1.56 \%$ & 3.99E-02 & $1.13 \%$ & 1.59E-02 & $0.96 \%$ & 2.20E-03 & $1.33 \%$ \\
\hline
\end{tabular}

Average values of the $\mathrm{X}^{+/ 30} \mathrm{Si}$ or $\mathrm{X}^{+/ 44} \mathrm{Ca}$ and their variation in percent (1 RSD) of all SIMS measurements. $\mathrm{X}$ refers to the isotope of interest which is ratioed against reference isotopes ${ }^{44} \mathrm{Ca}$ and ${ }^{30} \mathrm{Si}$, e.g., the ${ }^{85} \mathrm{Rb} /{ }^{30} \mathrm{Si}^{+}$ratio in TNT 150 was $0.00638 \pm 0.00005$.

the CPX glasses) were analysed with LA-ICP-MS (Figure 1, Table 4). We express the variation across samples in terms of the relative standard deviation (RSD) of multiple analyses across several glass fragments in percent. We also performed some homogeneity tests on glasses using SIMS techniques (Figure 2). Since relevant microanalytical reference materials for phosphates and titanites were not available, we used ratios of doped trace elements ${ }^{30} \mathrm{Si}$ or ${ }^{44} \mathrm{Ca}$ to investigate homogeneity of our glass samples. As an example, Table 5 lists results from SIMS analyses of several fragments of the TNT150, TNT1500, STDP5 and STD3-150 glasses. We used the relative standard deviation ( $1 s$ ) as a measure of reproducibility. In summary, we observed that variations for all trace elements of interest (i.e., the ones which we had doped) were often much lower than $2 \%$ relative for both glasses with the notable exception of $\mathrm{Pb}$ which suffered from low ion yields during SIMS determination and consequently poor counting statistics.

In summary, electron microprobe analysis and detailed studies using SIMS and laser ablation ICPMS indicated that the individual glass fragments were homogenous with respect to both major and all studied trace elements at the $\mu \mathrm{m}$ to $\mathrm{mm}$ scale. Repetitive measurements of most trace elements varied within the analytical uncertainties, that is, within a few percent.

\section{Analytical results}

Table 6 lists analytical results from all measurements on our eight glasses. The results include measurements with solution ICP-MS, laser ablation ICP-MS, and isotope dilution multi-collector ICP-MS.

\section{Provisional recommended values}

Table 7 lists provisional recommended values and other analytical results classified as information values. As our glasses were analysed with several different analytical techniques with different inherent uncertainties, we used the following rationale to determine which values were suitable for recommendation and which analytical data were of information value only. Preferred were data from isotope dilution multi collector-inductively coupled plasma-mass spectrometry (MC-ICP-MS) because of the excellent accuracy and reproducibility of the measurements. Unfortunately, we can only present measurements for selected number elements such as $\mathrm{Zr}, \mathrm{HF}, \mathrm{Nb}$, Ta and Lu. The MC-ICPMS data for these elements were selected as recommended values.

Further measurements on our glasses were performed using solution ICP-MS and laser ablation ICP-MS. We chose to recommend analytical results from these 


\begin{tabular}{|c|c|c|}
\hline & 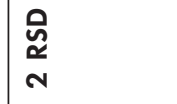 & 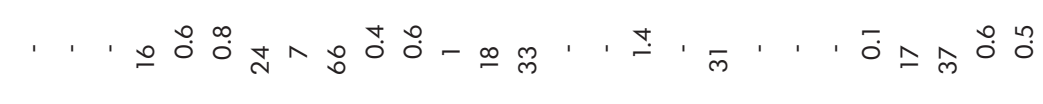 \\
\hline & 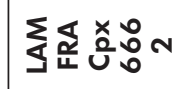 & 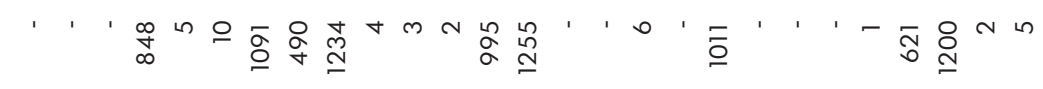 \\
\hline & 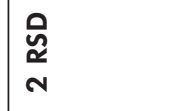 & 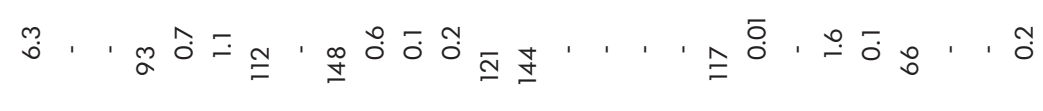 \\
\hline & 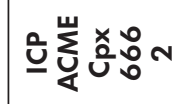 & 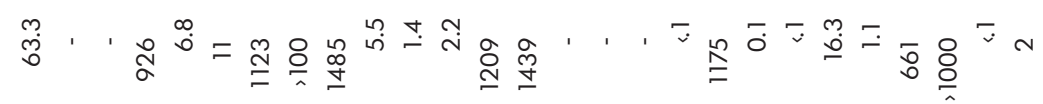 \\
\hline & 言 & 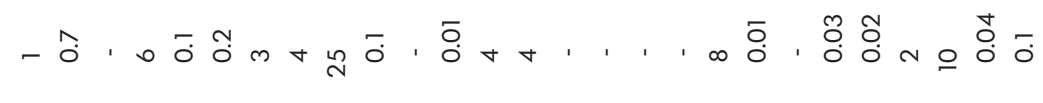 \\
\hline ? & $\sum_{S} z_{<}^{x} 00$ & 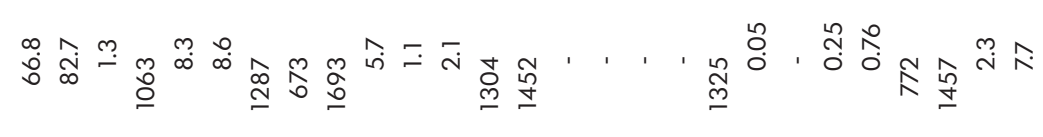 \\
\hline$\frac{n}{\stackrel{0}{0}}$ & 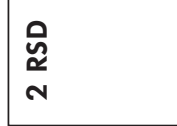 & 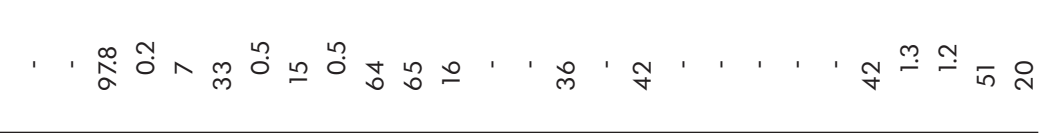 \\
\hline 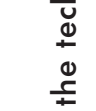 & 迎占叔 & 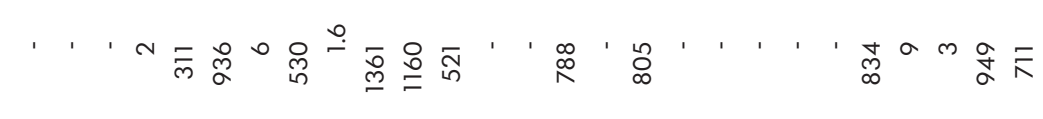 \\
\hline 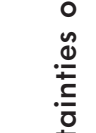 & 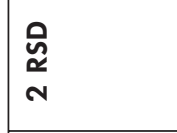 & б. , , 苟 \\
\hline 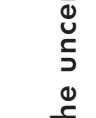 & 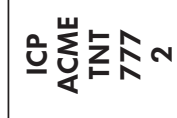 & 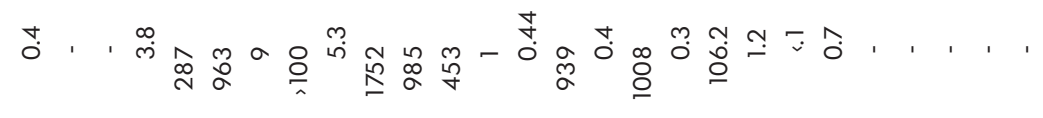 \\
\hline 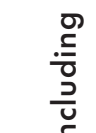 & 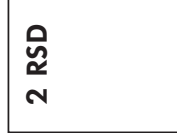 & 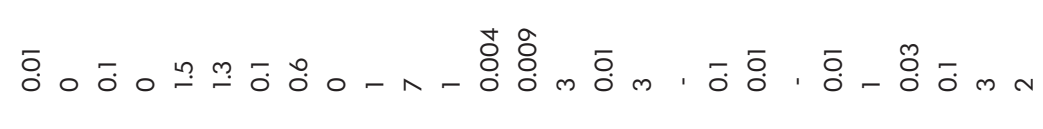 \\
\hline 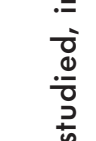 & 弦々卡。 & 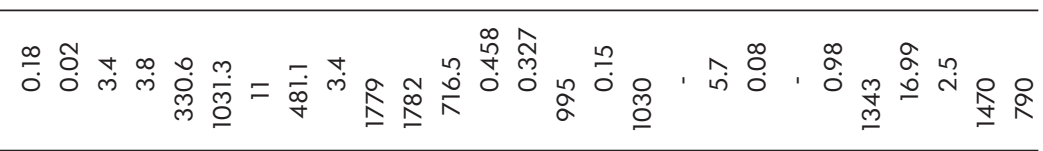 \\
\hline 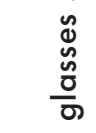 & 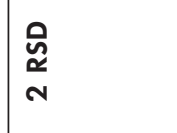 & 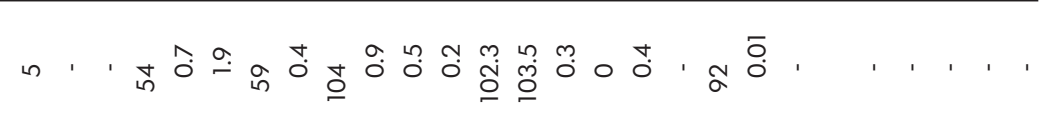 \\
\hline 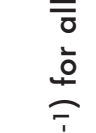 & îㄴ⿺ㄴ & 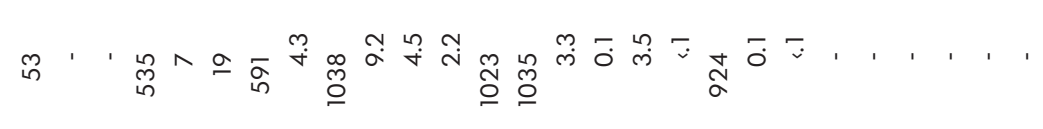 \\
\hline 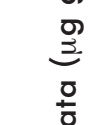 & $\underset{\substack{\omega \\
\text { N }}}{ }$ & - ஜํㅇ n \\
\hline 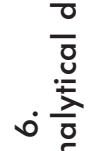 & 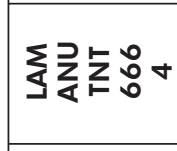 & ๘ \\
\hline$\underline{\underline{n}} \bar{z}$ & & 2 \\
\hline
\end{tabular}




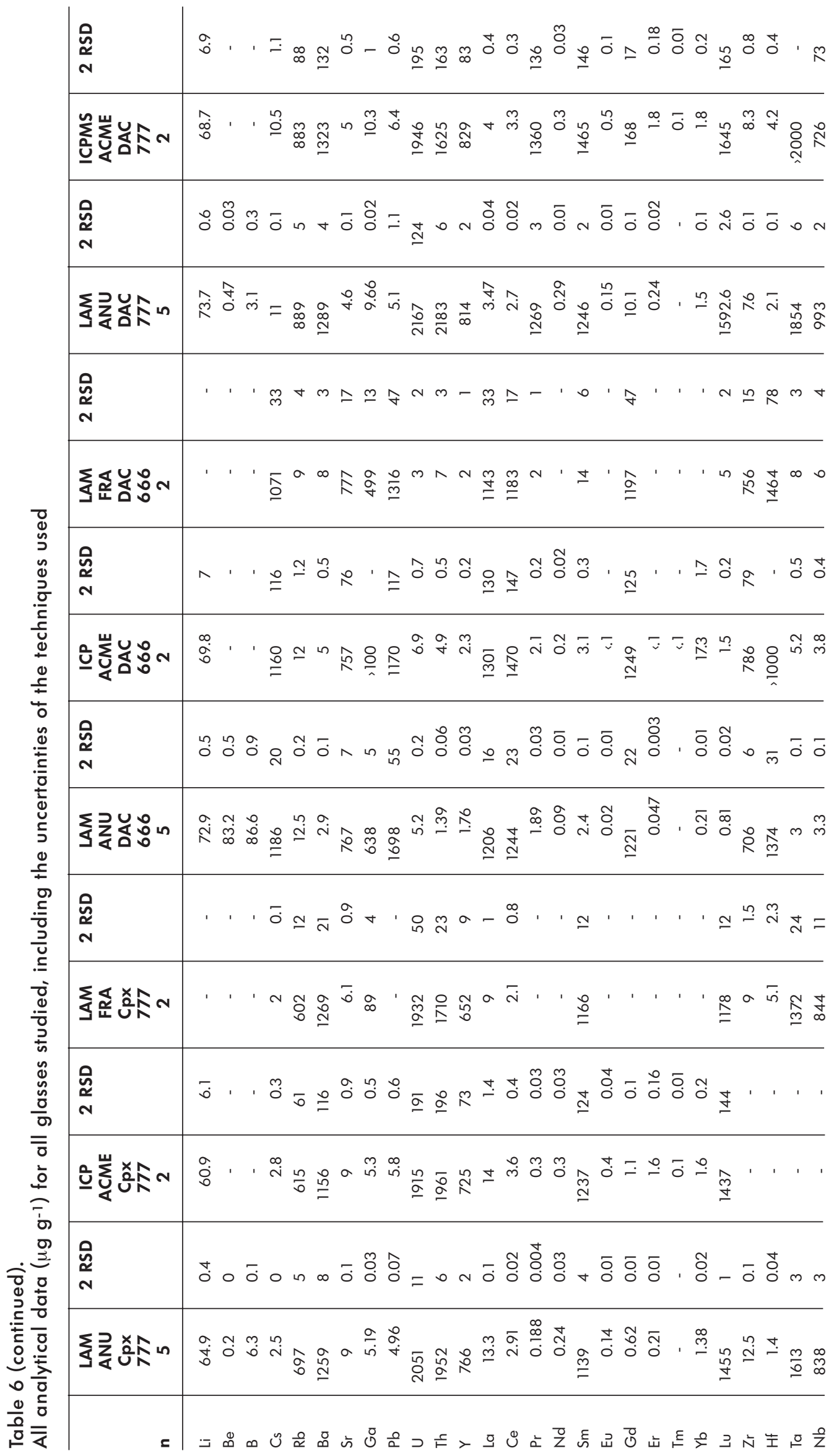




\begin{tabular}{|c|c|c|c|}
\hline & फे & ' ' ' ' ' ' ' ' & $\begin{array}{l}0 \\
8 \\
8\end{array}$ \\
\hline & 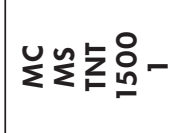 & 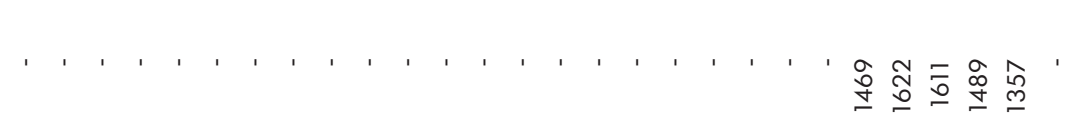 & 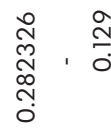 \\
\hline & Wh & $\varrho$ ' ' & \\
\hline & 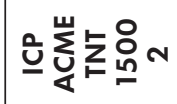 & $\stackrel{\circ}{\circ}$ ' ' & ' \\
\hline & 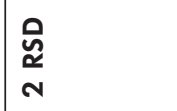 & 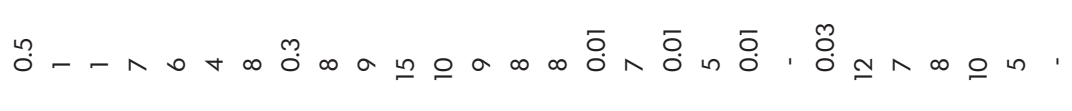 & , \\
\hline & 旅卡员。 & 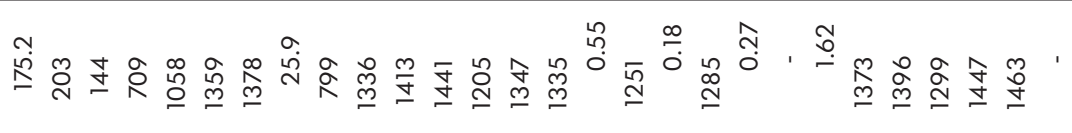 & ' \\
\hline 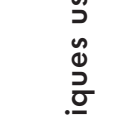 & $\begin{array}{l}P \\
\text { a } \\
\text { N }\end{array}$ & 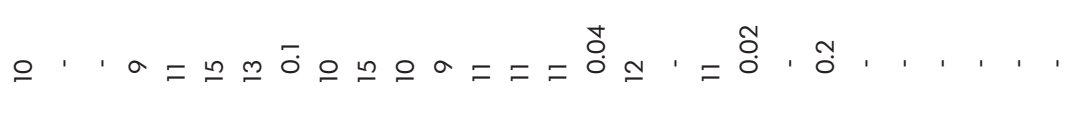 & . \\
\hline 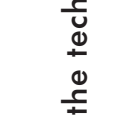 & 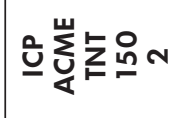 & ڤ ' ' ’ & ' \\
\hline 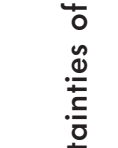 & $\begin{array}{l}\text { Wิ } \\
\text { N }\end{array}$ & 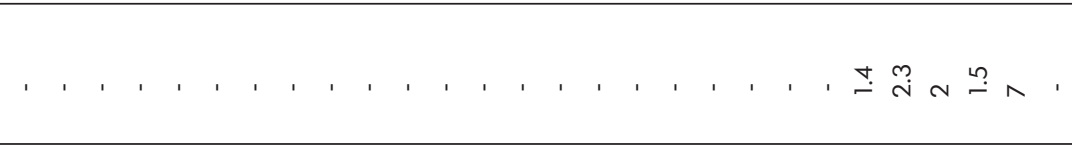 & 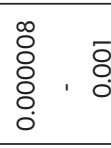 \\
\hline 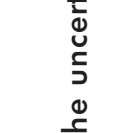 & 玹玹々员一 & 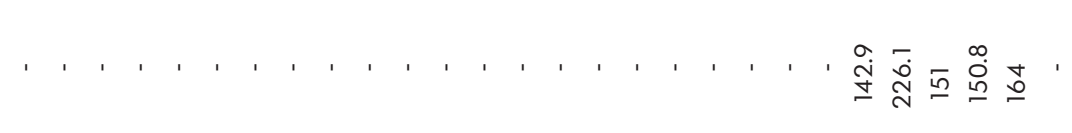 & 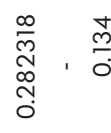 \\
\hline 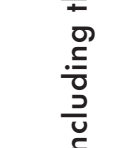 & 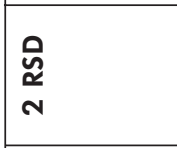 & $\cdot, \cdot, \cdot, \cdot, \cdot, \cdot, \cdot, \cdot, \cdot 1$ & $\begin{array}{l}\circ \\
: \\
: \\
\circ \\
\circ\end{array}$ \\
\hline 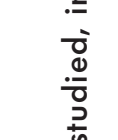 & 比员占员一 & 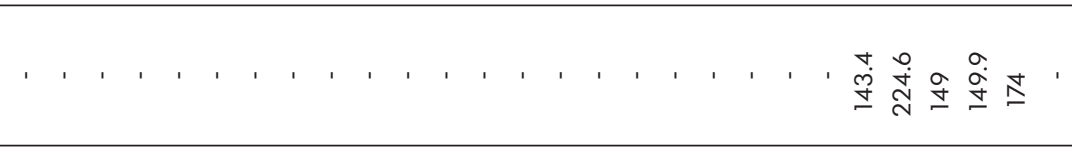 & 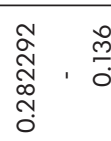 \\
\hline 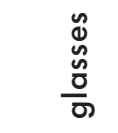 & $\begin{array}{l}\text { Wิ } \\
\text { N }\end{array}$ & 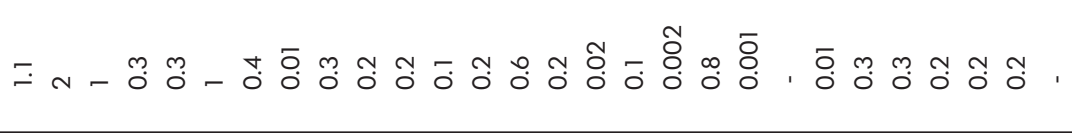 & , \\
\hline 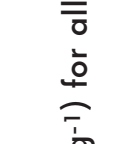 & 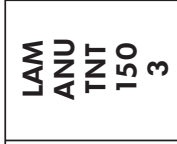 & 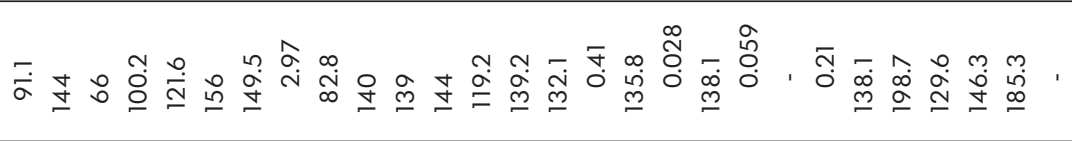 & ' \\
\hline 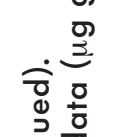 & $\begin{array}{l}\text { 紋 } \\
\text { N }\end{array}$ & 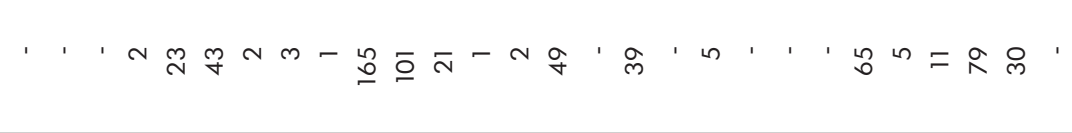 & ' \\
\hline 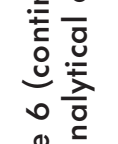 & 巡幾N & 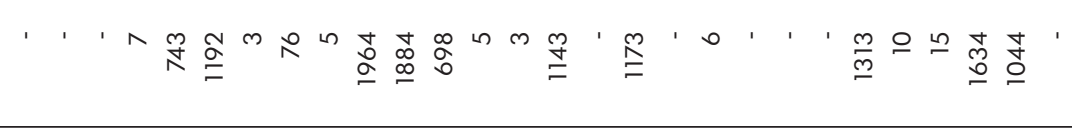 & ' \\
\hline$=$ & & 0 & \\
\hline
\end{tabular}


Table 6 (continued).

All analytical data ( $\left.\mathrm{g} \mathrm{g} \mathrm{g}^{-1}\right)$ for all glasses studied, including the uncertainties of the techniques used

\begin{tabular}{|c|c|c|c|c|c|c|c|c|c|c|}
\hline n & $\begin{array}{c}\text { LAM } \\
\text { ANU } \\
\text { STDP3 } \\
150 \\
4\end{array}$ & 2 RSD & $\begin{array}{c}\text { ICP } \\
\text { ACME } \\
\text { STDP3 } \\
150 \\
2\end{array}$ & 2 RSD & $\begin{array}{c}\text { LAM } \\
\text { ANU } \\
\text { STDP3 } \\
1500 \\
5\end{array}$ & 2 RSD & $\begin{array}{c}\text { LAM } \\
\text { ANU } \\
\text { STDP } \\
5 \\
5\end{array}$ & 2 RSD & $\begin{array}{c}\text { ICP } \\
\text { ACME } \\
\text { STDP } \\
5 \\
2\end{array}$ & 2 RSD \\
\hline $\mathrm{Li}$ & 12.8 & 0.2 & 11.8 & 1.2 & 99 & 1 & 88 & 1 & 89 & 9 \\
\hline $\mathrm{Be}$ & 10.7 & 0.1 & - & - & 99.5 & 0.4 & 88.3 & 0.4 & - & - \\
\hline B & 65.6 & 0.2 & - & - & 159 & 1 & 59.1 & 0.3 & - & - \\
\hline Cs & 148 & 1.6 & 136 & 14 & 1495 & 12 & 1268 & 9 & 1441 & 144 \\
\hline $\mathrm{Rb}$ & 153 & 1.4 & 136 & 14 & 1545 & 12 & 1310 & 8 & 1585 & 158 \\
\hline $\mathrm{Ba}$ & 153 & 0.7 & 157 & 16 & 1520 & 5 & 1396 & 10 & 1481 & 148 \\
\hline $\mathrm{Sr}$ & 200 & 0.6 & 193 & 19 & 1474 & 6 & 1420 & 4 & 1448 & 145 \\
\hline $\mathrm{Ga}$ & 17 & 0.1 & 13 & 1 & 42.9 & 0.2 & 37.4 & 0.3 & 5 & 0.5 \\
\hline $\mathrm{Pb}$ & 158 & 0.6 & 145 & 14 & 1584 & 13 & 1327 & 15 & 1501 & 150 \\
\hline$U$ & 145 & 1 & 143 & 14 & 1446 & 7 & 1385 & 21 & 1371 & 137 \\
\hline Th & 142 & 0.9 & 156 & 16 & 1434 & 8 & 1423 & 18 & 1046 & 105 \\
\hline$Y$ & 134 & 0.8 & 142 & 14 & 1426 & 7 & 1475 & 3 & 1470 & 147 \\
\hline La & 118 & 0.4 & 119 & 12 & 1241 & 7 & 1214 & 11 & 1219 & 122 \\
\hline $\mathrm{Ce}$ & 148 & 0.9 & 145 & 15 & 1522 & 6 & 1468 & 12 & 1533 & 153 \\
\hline $\operatorname{Pr}$ & 136 & 0.6 & 127 & 13 & 1425 & 6 & 1390 & 12 & 1496 & 150 \\
\hline $\mathrm{Nd}$ & 0.19 & 0.02 & 0.3 & 0.03 & 0.4 & 0.04 & 0.25 & 0.01 & 0.55 & 0.06 \\
\hline $\mathrm{Sm}$ & 127 & 1 & 127 & 13 & 1282 & 4 & 1224 & 11 & 1467 & 147 \\
\hline Eu & - & - & 0.1 & 0.01 & 0.16 & 0.01 & 0.147 & 0.003 & 0.5 & 0.1 \\
\hline Gd & 125 & 1 & 123 & 12 & 1281 & 5 & 1315 & 15 & 1434 & 143 \\
\hline $\mathrm{Er}$ & 0.05 & 0.01 & 0.2 & 0.02 & 0.23 & 0.02 & 0.21 & 0.01 & 1.7 & 0.2 \\
\hline $\mathrm{Tm}$ & - & - & $<.1$ & - & - & - & - & - & 0.1 & 0.01 \\
\hline $\mathrm{Yb}$ & 0.2 & 0.01 & 1.9 & 0.2 & 1.5 & 0.1 & 1.5 & 0.1 & 19 & 2 \\
\hline Lu & 136 & 1 & 138 & 14 & 1407 & 10 & 1439 & 18 & 1419 & 142 \\
\hline $\mathrm{Zr}$ & 133 & 2 & 151 & 15 & 1301 & 6 & 1335 & 6 & - & - \\
\hline $\mathrm{Hf}$ & 129 & 1 & 161 & 16 & 1306 & 7 & 1344 & 19 & - & - \\
\hline $\mathrm{Ta}$ & 148 & 1 & 193 & 19 & 1518 & 10 & 1463 & 17 & - & - \\
\hline $\mathrm{Nb}$ & 149 & 1 & 143 & 14 & 1521 & 9 & 1285 & 8 & - & - \\
\hline
\end{tabular}

ICP: results from solution ICP-MS measurements, LAM: results from laser ablation ICP-MS measurements, MC: results from isotope dilution multicollector ICP-MS measurements. Given are average values from numerous individual measurements $(n=$ number of analyses) with associated RSDs of the analytical techniques. Two analyses from isotope dilution multi-collector ICP-MS of the TNT 150 samples are given as individual results. FRA: University of Frankfurt Germany; MS: University of Münster, Germany; ACME: ACME Laboratories, Vancouver, Canada; ANU: Australian National University, Canberra, Australia.

Table 7.

Selected provisional recommended values $\left(\mu \mathrm{g} \mathrm{g}^{-1}\right)$ and some other analytical results $\left(\mu \mathrm{g} \mathrm{g}^{-1}\right)$ with information value only for the glasses

\begin{tabular}{|c|c|c|c|c|c|c|c|c|c|c|c|c|}
\hline & $\begin{array}{c}\text { TNT } \\
666 \\
\text { Recommended } \\
\text { value }\end{array}$ & 2 RSD & $\begin{array}{c}\text { Information } \\
\text { value }\end{array}$ & $2 s$ & $\begin{array}{c}\text { TNT } \\
777 \\
\text { Recommended } \\
\text { value }\end{array}$ & 2 RSD & $\begin{array}{c}\text { Information } \\
\text { value }\end{array}$ & 2 RSD & $\begin{array}{c}\text { CPX } \\
666 \\
\text { Recommended } \\
\text { value }\end{array}$ & 2 RSD & $\begin{array}{c}\text { Information } \\
\text { value }\end{array}$ & 2 RSD \\
\hline Li & 52 & 1.7 & - & - & - & - & - & - & 65 & 2.5 & - & - \\
\hline $\mathrm{Be}$ & - & - & 69 & 0.3 & - & - & - & - & - & - & 82.7 & 0.7 \\
\hline B & - & - & 47 & 0.7 & - & - & & - & - & - & 97.8 & 1.3 \\
\hline Cs & 528 & 10.2 & - & - & - & - & 3 & 1 & 946 & 109 & - & - \\
\hline $\mathrm{Rb}$ & 6.4 & 0.8 & - & - & 309 & 22 & - & - & 7 & 1.6 & - & - \\
\hline $\mathrm{Ba}$ & 16.2 & 3.9 & - & - & 977 & 49 & - & - & 10 & 1.2 & - & - \\
\hline $\mathrm{Sr}$ & 626 & 50 & - & - & - & - & 8.7 & 2.5 & - & - & 1167 & 105 \\
\hline $\mathrm{Ga}$ & - & - & 12 & 11 & 506 & 35 & - & - & - & - & 581 & 129 \\
\hline $\mathrm{Pb}$ & 974 & 90 & - & - & - & - & 3.4 & 1.8 & - & - & 1470 & 230 \\
\hline$U$ & - & - & 5.8 & 4.7 & 1630 & 234 & - & - & - & - & 5 & 0.9 \\
\hline Th & - & - & 0.32 & 0.01 & - & - & 1309 & 419 & - & - & 2 & 1 \\
\hline Y & - & - & 1.5 & 1.1 & - & - & 564 & 137 & 2 & 0.1 & - & - \\
\hline La & 1032 & 13 & - & - & - & - & 0.73 & 0.38 & - & - & 1169 & 158 \\
\hline $\mathrm{Ce}$ & 1058 & 32 & - & - & - & - & 0.38 & 0.08 & - & - & 1382 & 110 \\
\hline $\operatorname{Pr}$ & - & - & - & - & 967 & 40 & - & - & - & - & 0.21 & 0.13 \\
\hline
\end{tabular}


Table 7 (continued).

Selected provisional recommended values ( $\mathrm{gg} \mathrm{g}^{-1}$ ) and some other analytical results $\left(\mu \mathrm{g} \mathrm{g}^{-1}\right)$ with information value only for the glasses

\begin{tabular}{|c|c|c|c|c|c|c|c|c|c|c|c|c|}
\hline & $\begin{array}{c}\text { TNT } \\
666 \\
\text { Recommended } \\
\text { value }\end{array}$ & 2 RSD & $\begin{array}{l}\text { Information } \\
\text { value }\end{array}$ & $2 s$ & $\begin{array}{c}\text { TNT } \\
777 \\
\begin{array}{c}\text { Recommended } \\
\text { value }\end{array}\end{array}$ & 2 RSD & $\begin{array}{c}\text { Information } \\
\text { value }\end{array}$ & 2 RSD & \begin{tabular}{|c|} 
CPX \\
666 \\
$\begin{array}{c}\text { Recommended } \\
\text { value }\end{array}$
\end{tabular} & 2 RSD & $\begin{array}{c}\text { Information } \\
\text { value }\end{array}$ & 2 RSD \\
\hline $\mathrm{Nd}$ & - & - & 0.07 & 0.04 & - & - & 0.27 & 0.18 & - & - & 0.08 & 0.03 \\
\hline $\mathrm{Sm}$ & - & - & - & - & 1019 & 16 & - & - & - & - & - & - \\
\hline Eu & - & - & - & - & - & - & 0.15 & 0.21 & - & - & - & - \\
\hline Gd & 996 & 103 & - & - & - & - & - & - & 1170 & 157 & - & - \\
\hline $\mathrm{Tb}$ & - & - & - & - & - & - & - & - & - & - & - & - \\
\hline Dy & - & - & - & - & - & - & - & - & - & - & - & - \\
\hline Ho & - & - & - & - & - & - & - & - & - & - & - & - \\
\hline Er & - & - & - & - & - & - & - & - & - & - & 0.07 & 0.04 \\
\hline $\mathrm{Tm}$ & - & - & - & - & - & - & - & - & - & - & - & - \\
\hline $\mathrm{Yb}$ & - & - & 0.19 & 0.01 & - & - & 1 & 0.2 & - & - & - & - \\
\hline Lu & - & - & 0.21 & 0 & 1343 & 1 & - & - & - & - & 1 & 0.2 \\
\hline $\mathrm{Zr}$ & 667 & 2 & - & - & 16.99 & 0.03 & - & - & 685 & 78 & - & - \\
\hline $\mathrm{Hf}$ & 1262 & 7 & - & - & - & - & 2.5 & 0.1 & 1329 & 182 & - & - \\
\hline $\mathrm{Ta}$ & 3.29 & 0.03 & - & - & 1470 & 3 & - & - & - & - & 2.1 & 0.2 \\
\hline $\mathrm{Nb}$ & 44.96 & 0.04 & - & - & 790 & 2 & - & - & - & - & 4.9 & 2.9 \\
\hline & $\begin{array}{c}\text { CPX } \\
777 \\
\text { Recommended } \\
\text { value }\end{array}$ & 2 RSD & $\begin{array}{l}\text { Information } \\
\text { value }\end{array}$ & 2 RSD & \begin{tabular}{|c|} 
DAC \\
666 \\
$\begin{array}{c}\text { Recommended } \\
\text { value }\end{array}$
\end{tabular} & 2 RSD & $\begin{array}{c}\text { Information } \\
\text { value }\end{array}$ & 2 RSD & \begin{tabular}{|c|} 
DAC \\
777 \\
$\begin{array}{c}\text { Recommended } \\
\text { value }\end{array}$
\end{tabular} & 2 RSD & $\begin{array}{c}\text { Information } \\
\text { value }\end{array}$ & 2 RSD \\
\hline Li & 63 & 2.9 & - & - & 71 & 2 & - & - & 71 & 3.5 & - & - \\
\hline $\mathrm{Be}$ & - & - & - & - & - & - & 83.2 & 0.5 & - & - & 0.5 & 0.03 \\
\hline B & - & - & 6.3 & 0.1 & - & - & 86.6 & 0.9 & - & - & 3.1 & 0.3 \\
\hline $\mathrm{Cs}$ & - & - & 2.4 & 0.4 & 1139 & 60 & - & - & - & - & 10 & 2.2 \\
\hline $\mathrm{Rb}$ & 638 & 52 & - & - & - & - & 11.2 & 1.9 & 838 & 83 & - & - \\
\hline $\mathrm{Ba}$ & 1228 & 63 & - & - & - & - & 5.3 & 2.6 & 1268 & 68 & - & - \\
\hline $\mathrm{Sr}$ & - & - & 8 & 1.7 & 767 & 10 & - & - & - & - & 4 & 1.1 \\
\hline Ga & - & - & 5 & 0.1 & 568 & 98 & - & - & - & - & 10 & 0.5 \\
\hline $\mathrm{Pb}$ & - & - & 5 & 0.6 & 1394 & 273 & - & - & - & - & 5 & 0.8 \\
\hline U & 1966 & 74 & - & - & - & - & 5 & 2 & 2025 & 123 & - & - \\
\hline Th & 1874 & 142 & - & - & - & - & 4 & 2.8 & 1898 & 279 & - & - \\
\hline Y & 714 & 58 & - & - & 2 & 0.3 & - & - & 780 & 72 & - & - \\
\hline La & - & - & 12 & 2.7 & 1217 & 80 & - & - & - & - & 4 & 0.8 \\
\hline $\mathrm{Ce}$ & - & - & 2.9 & 0.8 & 1299 & 151 & - & - & - & - & 3 & 0.3 \\
\hline $\operatorname{Pr}$ & - & - & 0.2 & 0.1 & - & - & 2 & 0.1 & 1258 & 109 & - & - \\
\hline $\mathrm{Nd}$ & - & - & 0.27 & 0.04 & - & - & - & - & - & - & 0.29 & 0.01 \\
\hline Sm & 1181 & 50.8 & - & - & - & - & 3 & 0.5 & 1294 & 152 & - & - \\
\hline Eu & - & - & - & - & - & - & - & - & - & - & - & - \\
\hline Gd & - & - & 1 & 0.3 & 1222 & 26 & - & - & - & - & - & - \\
\hline $\mathrm{Tb}$ & - & - & - & - & - & - & - & - & - & - & - & - \\
\hline Dy & - & - & - & - & - & - & - & - & - & - & - & - \\
\hline Ho & - & - & - & - & - & - & - & - & - & - & - & - \\
\hline $\mathrm{Er}$ & - & - & - & - & - & - & - & - & - & - & - & - \\
\hline $\mathrm{Tm}$ & - & - & - & - & - & - & - & - & - & - & - & - \\
\hline $\mathrm{Yb}$ & - & - & 1.5 & 0.2 & - & - & - & - & - & - & 1.6 & 0.2 \\
\hline Lu & 1357 & 155 & - & - & - & - & - & - & 1517 & 179 & - & - \\
\hline $\mathrm{Zr}$ & - & - & 11 & 2.5 & 749 & 41 & - & - & - & - & 9 & 1.2 \\
\hline $\mathrm{Hf}$ & - & - & 3 & 2.6 & 1419 & 63 & - & - & - & - & 3 & 1.5 \\
\hline Ta & - & - & 1613 & 3 & - & - & 5 & 2.5 & 1744 & 156 & - & - \\
\hline $\mathrm{Nb}$ & 841 & 4.2 & - & - & - & - & 4 & 1.4 & 921 & 171 & - & - \\
\hline
\end{tabular}


Table 7 (continued).

Selected provisional recommended values $\left(\mu \mathrm{g} \mathrm{g}^{-1}\right)$ and some other analytical results ( $\left.\mu \mathrm{g} \mathrm{g}^{-1}\right)$ with information value only for the glasses

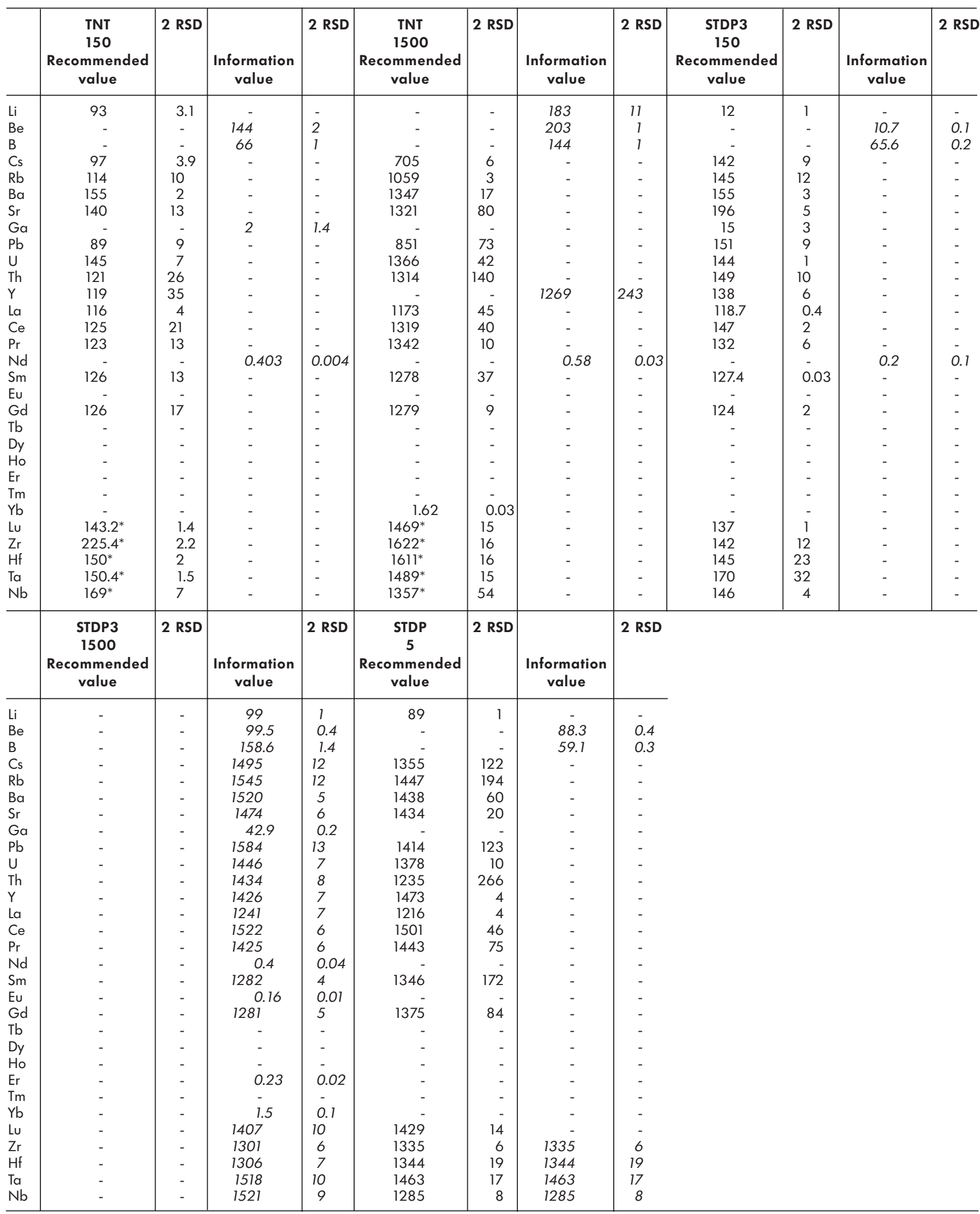

A selection of preliminary recommended values for the silicate, phosphate and titanite glasses studied. Other values with information value (italics) only are also given. Recommended values were only assigned to glasses when results from several analytical techniques agreed with each other to a variance of less than 15\%. *: recommended values based on isotope dilution MC-ICP-MS measurements only. 

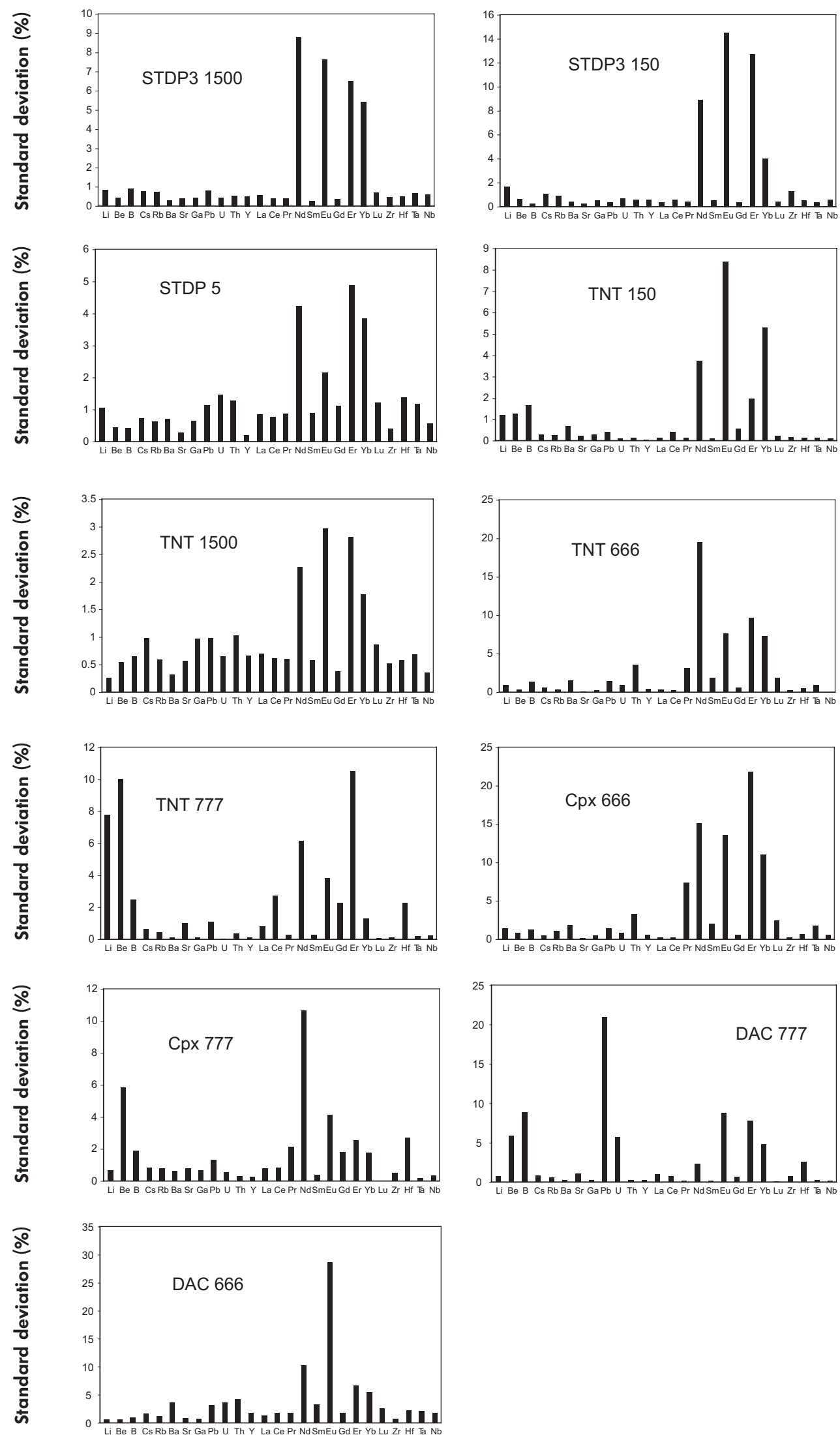

Figure 1. Homogeneity tests of all glasses using laser ablation ICP-MS.

Standard deviation is 2 RSD (percent) of multiple analyses. 

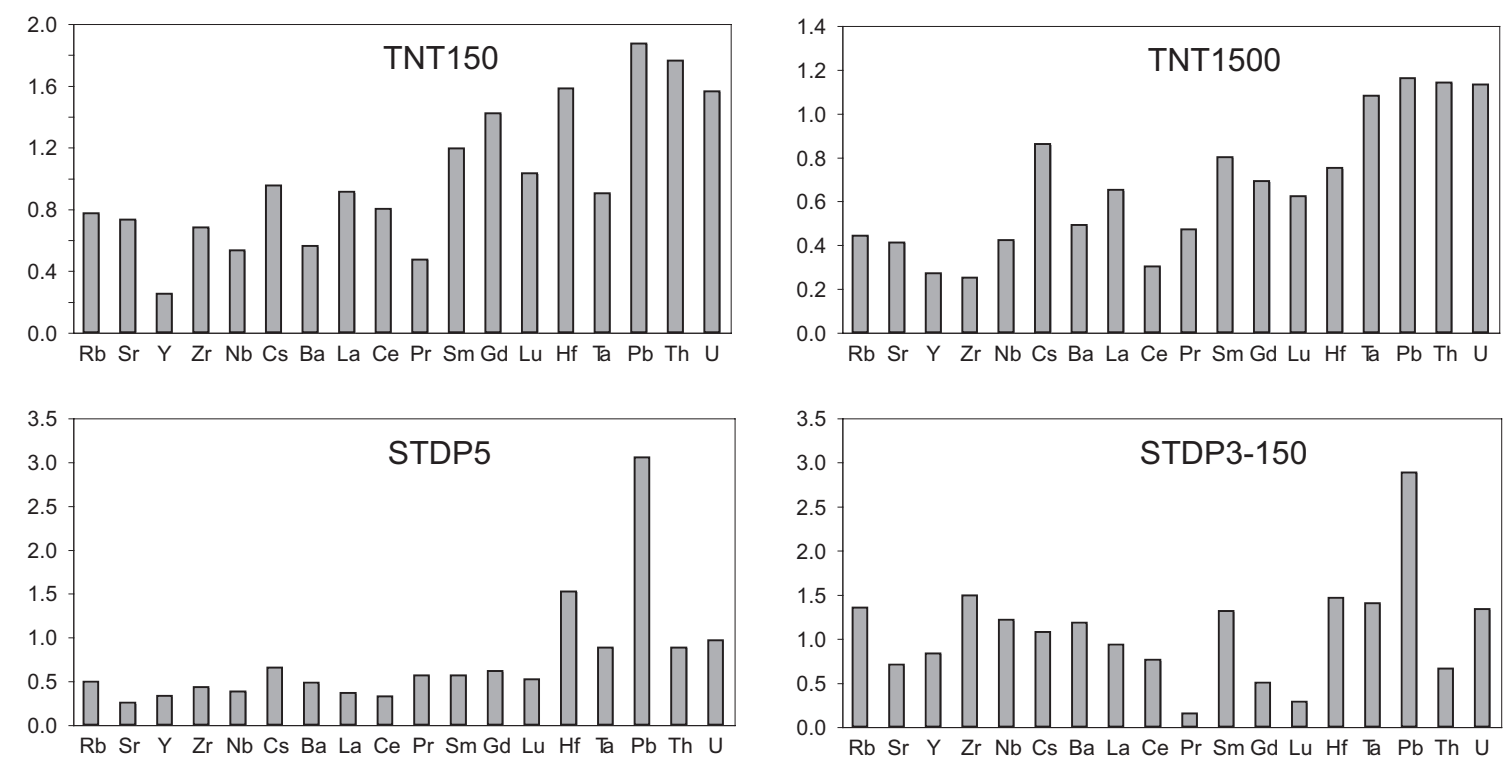

Figure 2. Homogeneity tests of some selected glasses using SIMS. Standard deviation is 1 RSD (percent) of multiple analyses.

measurements if results from several analytical techniques (mainly solution ICP-MS and LA-ICP-MS) agreed within $15 \%$. In this case, the recommended values consist of weighted averages with the associated standard deviations. Also, in cases where we have only measurements using one analytical technique, i.e., in the case of $\mathrm{Be}$ and $\mathrm{B}$, or the STDP31500 glass, these data were regarded as information values only.

\section{Possible applications}

Our new glasses may be used as reference samples for the trace element analysis of accessory minerals such as apatite, titanite or other phosphates or titanites. This may be of interest to those who study the behaviour of trace elements in igneous and metamorphic rocks or those who aim to date the crystallisation of accessory minerals. Recent advances in in situ dating techniques with ion probe or laser ablation ICP-MS has renewed the interest in accessory minerals especially titanite and apatite. Our new reference materials may prove helpful during the characterisation of these minerals. Further, as our TNT glasses have been characterised for trace element concentrations as well as in $176 \mathrm{Hf} / 177 \mathrm{Hf}$ and 176 Lu/177 Hf isotopic data, they may also be of interest to those who intend to measure the $\mathrm{Hf}$ isotopic composition of titanites.
Furthermore, apatite and titanite are important minerals used in fission-track dating (e.g., Hasebe et al. 2004). As there is no accepted apatite reference material which could be used to calibrate $U$ or Th contents, our STDP glasses may be of use for the measurement of $U$ and Th. During the course of this study it became apparent that $U$ concentrations measured by SIMS gave highly consistent results. For example, U/Ti SIMS sensitivity factors for TNT150 and TNT1500 agreed within 12\% (2s) with those derived from measurements of USGS and MPI-DING glasses (Luvizotto et al. in prep). This may be taken as evidence for only weak, if any, matrix dependency of $U$ concentration measured with SIMS, using the conditions employed in this study. We believe that this should encourage more advanced fission-track dating studies where $U$ concentrations in apatite are determined in situ close to the area of fission track counting rather than from conventional bulk neutron activation analysis (Cox et al. 2000, Hasebe et al. 2004). Both the titanite glasses (TNT150 and TNT1500) and the apatite glasses (STDP5 and STDP3-150) are homogeneous within $3 \%$ for all measured trace elements (Tables 4 and 5). These glasses are therefore ideal candidates for reference materials for apatite and titanite fission track dating (Hasebe et al. 2004). We are willing to share small amounts of the presented reference materials to the scientific community on request (stephan.klemme@ed.ac.uk or stefan.prowatke@swarovski.com), reserving the right to charge a fee to cover costs. 


\section{Acknowledgements}

SK would like to thank the Leverhulme Trust for support. Our thanks go to an anonymous reviewer for a very helpful review. We are indebted to Thomas Ludwig and Hans-Peter Meyer at Heidelberg University for their sterling efforts with the microprobe and ion probe facilities. Moreover, we would like to thank Hugh O'Neill for his generous support during SK and SAK's stay at the Australian National University. Thanks also to Kay Provins for administrative support during this stay.

\section{References}

Black L.P., Kamo S.L., Allen C.M., Aleinikoff J.N., Davis D.W., Korsch R.J. and Foudoulis C. (2003) TEMORA 1: A new zircon standard for Phanerozoic U-Pb geochronology. Chemical Geology, 200, 155-170.

Black L.P., Kamo S.L., Allen C.M., Davis D.W., Aleinikoff J.N., Valley J.W., Mundil R.,

Campbell I.H., Korsch R.J., Williams I.S. and Foudoulis C. (2004)

Improved Pb-206/U-218 microprobe geochronology by the monitoring of a trace-element-related matrix effect; SHRIMP, ID-TIMS, ELA-ICP-MS and oxygen isotope documentation for a series of zircon standards. Chemical Geology, 205, 115-140.

Cox R., Kosler J., Sylvester P. and Hodych J. (2000) Apatite fission-track dating by LAM-ICP-MS analysis. Journal of Conference Abstracts, 5, 322.

Eggins S.M., Grün R., Pike A.W.G., Shelley J.M.G. and Taylor L. (2003)

238U, 232Th profiling and U-series isotope analysis of fossil teeth by laser ablation-ICPMS. Quaternary Science Reviews, 22, 1373-1382.

Hasebe N., Barbarand J., Jarvis K., Carter A. and Hurford A.J. (2004)

Apatite fission-track chronometry using laser ablation ICP-MS. Chemical Geology, 207, 135-145.

Jochum K.P., Dingwell D.B., Rocholl A., Stoll B., Hofmann A.W., Becker S., Besmehn A., Bessette D., Dietze H.J., Dulski P., Erzinger J., Hellebrand E., Hoppe P., Horn I., Janssens K., Jenner G.A., Klein M., McDonough W.F., Maetz M., Mezger K., Münker C., Nikogosian I.K., Pickhardt C., Raczek I. Rhede D., Seufert H.M., Simakin S.G., Sobolev A.V., Spettel B., Straub S., Vincze L., Wallianos A., Weckwerth G., Weyer S., Wolf D. and Zimmer M. (2000)

The preparation and preliminary characterisation of eight geological MPI-DING reference glasses for in-situ microanalysis. Geostandards Newsletter: The Journal of Geostandards and Geoanalysis, 24, 87-133.
Jochum K.P., Pfänder J., Woodhead J.D. Willbold M., Stoll B., Herwig K., Amini M. Abouchami W. and Hofmann A.W. (2005) MPI-DING glasses: New geological reference materials for in situ $\mathrm{Pb}$ isotope analysis. Geochemistry Geophysics Geosystems, 6.

Jochum K.P., Stoll B., Herwig K., Willbold M., Hofmann A.W., Amini M., Aarburg S.,

Abouchami W., Hellebrand E., Mocek B., Raczek I., Stracke A., Alard O., Bouman C., Becker S., Ducking M., Bratz H., Klemd R., de Bruin D., Canil D., Cornell D., de Hoog C.J., Dalpe C., Danyushevsky L., Eisenhaver A., Gao Y., Snow J.E., Groschopf N., Günther D., Latkoczy C., Guillong M., Hauri E.H., Höfer H.E., Lahaye Y., Horz K., Jacob D.E., Kasemann S.A., Kent A.J.R., Ludwig T., Zack T., Mason P.R.D., Meixner A., Rosner M., Misawa K., Nash B.P., Pfänder J., Premo W.R., Sun W.D.D., Tiepolo M., Vannucci R., Vennemann T., Wayne D. and Woodhead J.D. (2006) MPI-DING reference glasses for in situ microanalysis: New reference values for element concentrations and isotope ratios. Geochemistry Geophysics Geosystems, 7.

McDowell F.W., Mclntosh W.C. and Farley K.A. (2005)

A precise ${ }^{40 \mathrm{Ar}-39} \mathrm{Ar}$ reference age for the Durango apatite (U-Th)/He and fission-track dating standard. Chemical Geology, 214, 249-263.

\section{Münker C., Weyer S., Scherer E.E. and} Mezger K. (2001)

Separation of high field strength elements $(\mathrm{Nb}, \mathrm{Ta}, \mathrm{Zr}, \mathrm{Hf})$ and Lu from rock samples for MC-ICPMS measurements. Geochemistry, Geophysics, Geosystems, 2,

10.1029/2001 GC000183.

Ødegaard M., Skaar Ø., Schiellerup H. and Pearson N.J. (2005)

Preparation of a synthetic titanite glass calibration material for in situ microanalysis by direct fusion in graphite electrodes: A preliminary characterisation by EPMA and LA-ICP-MS. Geostandards and Geoanalytical Research, 29, 197-209.

Pearce N.J.G., Perkins W.T., Westgate J.A., Gorton M.P., Jackson S.E., Neal C.R. and Chenery S.P. (1997)

A compilation of new and published major and trace element data for NIST SRM 610 and NIST SRM 612 glass reference materials. Geostandards Newsletter: The Journal of Geostandards and Geoanalysis, 21, 115-144.

Prowatke S. and Klemme S. (2005)

Effect of melt composition on the partitioning of trace elements between titanite and silicate melt. Geochimica et Cosmochimica Acta, 69, 695-709.

Prowatke S. and Klemme S. (2006)

Trace element partitioning between apatite and silicate melts. Geochimica et Cosmochimica Acta, 70, 4513-4527.

Sinha M.K., Sen P.S. and Basu D. (2001)

Synthesis, sintering and microstructure of beta-tricalcium phosphate for prosthetic applications. Journal of the Indian Chemical Society, 78, 386-388. 


\section{GEOSTANDARDS and \\ GEOANALYTICAL \\ RESEARCH}

\section{references}

Sylvester P.J. and Ghaderi M. (1997)

Trace element analysis of scheelite by excimer laser

ablation inductively coupled plasma-mass spectrometry

(ELA-ICP-MS) using a synthetic silicate glass standard.

Chemical Geology, 141, 49-65.

Weyer S., Münker C., Rehkämper M. and Mezger K. (2002)

Determination of ultra-low $\mathrm{Nb}, \mathrm{Ta}, \mathrm{Zr}$ and $\mathrm{Hf}$

concentrations and the chondritic $\mathrm{Zr} / \mathrm{Hf}$ and $\mathrm{Nb} / \mathrm{Ta}$ ratios

by isotope dilution analyses with multiple collector

ICP-MS. Chemical Geology, 187, 295-313.

Wiedenbeck M., Allé P., Corfu F., Griffin W.L.,

Meier M., Oberli F., von Quadt A., Roddick J.C. and Spiegel W. (1995)

Three natural zircon standards for U-Th-Pb, Lu-Hf, trace-element and REE analyses. Geostandards Newsletter, 19, 1-23. 